\title{
Pathways out of poverty during an economic crisis: An empirical assessment of rural Indonesia
}

\author{
Neil McCulloch ${ }^{1}$ \\ Julian Weisbrod ${ }^{2}$ \\ C. Peter Timmer ${ }^{3}$
}

\section{Summary}

Most poor people in developing countries still live in rural areas and are primarily engaged in low productivity farming activities. Thus pathways out of poverty are likely to be strongly connected to productivity increases in the rural economy, whether they are realized in farming, in rural non-farm enterprises or by rural-urban migration. We use cross-sectional data from the Central Statistical Board for 1993 and 2002, as well as a panel data set from the Indonesia Family Life Survey for 1993 and 2000, to show which pathways out of poverty were most successful over this period. Our findings suggest that increased engagement of farmers in rural non-farm enterprises is an important route out of rural poverty, but that most of the rural agricultural poor that exit poverty still do so while remaining rural and agricultural. Thus changes in agricultural prices, wages and productivity still play a critical role in moving people out of poverty.

World Bank Policy Research Working Paper 4173, March 2007

The Policy Research Working Paper Series disseminates the findings of work in progress to encourage the exchange of ideas about development issues. An objective of the series is to get the findings out quickly, even if the presentations are less than fully polished. The papers carry the names of the authors and should be cited accordingly. The findings, interpretations, and conclusions expressed in this paper are entirely those of the authors. They do not necessarily represent the view of the World Bank, its Executive Directors, or the countries they represent. Policy Research Working Papers are available online at http://econ.worldbank.org.

\section{Acknowledgements}

Our greatest debt is to Lina Marliani. She faithfully compiled the datasets used in this paper and produced many of the graphs and tables. In addition we would like to thank BPS for use of the data and DFID for funding the work of the INDOPOV team in the World Bank Office in Jakarta under which most of this work was done. Finally we would like to thank numerous colleagues in Jakarta, Göttingen, Washington and elsewhere for useful comments and suggestions.

\footnotetext{
${ }^{1}$ Neil McCulloch, Senior Economist, World Bank Office Jakarta. Corresponding author: nmcculloch@,worldbank.org

${ }^{2}$ Julian Weisbrod, University of Göttingen, Germany.

${ }^{3}$ C. Peter Timmer, Center for Global Development, Washington D.C.
} 


\section{INTRODUCTION}

With the development community dedicated to meeting the Millennium Development Goals (MDGs), policy research has begun to focus on rigorous testing of models that explain MDG outcomes. Most basic, of course, is the goal of reducing poverty and hunger by half. Many "narrative" pathways out of poverty exist, but there are few quantitative models that have been tested over significant historical periods. One reason for this shortage of empirical results is a simple lack of data. Carefully tracing broadly representative pathways out of poverty requires long-term panel data on many individuals and households and are not available for many developing countries.

However, the number of panel data sets is growing and empirical pathways out of poverty are now being described. This paper reports on the pathways out of poverty in Indonesia during a period of economic and political turmoil. Since most poor people live in rural areas, special attention is devoted to rural pathways out of poverty. The generally positive results, even during this difficult period, hold broader promise for achievement of the MDGs.

Most of the world's poor live in rural areas and are primarily engaged in low productivity agricultural activities. Thus the main pathway out of poverty will be connected to increases in the productivity of the rural poor, whether these increases are realized in farming, in rural non-farm enterprises or by rural-urban migration. Indonesia provides an interesting case study for several reasons. First, between the late 1960s and the mid-1990s it experienced high and sustained economic growth, pulling millions of people out of poverty; second, it is large enough to display spatial and sectoral diversity, which are reflected in the large-scale household expenditure survey (SUSENAS) conducted regularly by the Central Bureau of Statistics (BPS); and third, it has a large household panel dataset, the Indonesia Family Life Survey (IFLS), which allows a detailed investigation of the characteristics of households that move in and out of poverty.

This paper draws on this Indonesian experience by using both cross-sectional data from SUSENAS and panel household survey data from IFLS to assess the importance of 
changes in sector and location in driving changes in individual incomes and household poverty over time. The paper is structured as follows: section 2 describes the conceptual framework and reviews the relevant theoretical and empirical literature; section 3 describes the data, shows the aggregate picture of sectoral and locational movements in employment, and provides a decomposition of income growth and poverty transitions according to sector and location; section 4 analyzes the micro-determinants of income and poverty changes using the IFLS panel data, before concluding with implications for policy in the final section.

\section{CONCEPTUAL BACKGROUND AND REVIEW OF THE LITERATURE}

Since the early works of Lewis (1954) one of the main questions in development economics has been the nature of the "structural transformation" that takes place as countries develop and how it influences growth and poverty reduction in the long term. Figure 1 presents a simple conceptual framework for how structural transformation translates into poverty reduction. We use this framework to organize our review of the literature and our later empirical work.

There are arguably two paths out of poverty. First is the move from low to high productivity farming (Pathway 1). This includes both intensification through raising productivity of traditional crops, as well as diversification into higher value crops, whether food or non-food. This pathway also includes those individuals who exit poverty by gaining better paid employment on higher productivity commercial farms. Thus staying in agriculture does not necessarily mean staying as a self-employed farmer.

Second, some people exit poverty because of increases in the productivity and profitability of their non-farm enterprises, or by finding better-paid employment in such enterprises (often more formal) owned by others (Pathway 2). This pathway applies to both rural and urban non-farm activities. 
Figure 1: Pathways out of Poverty

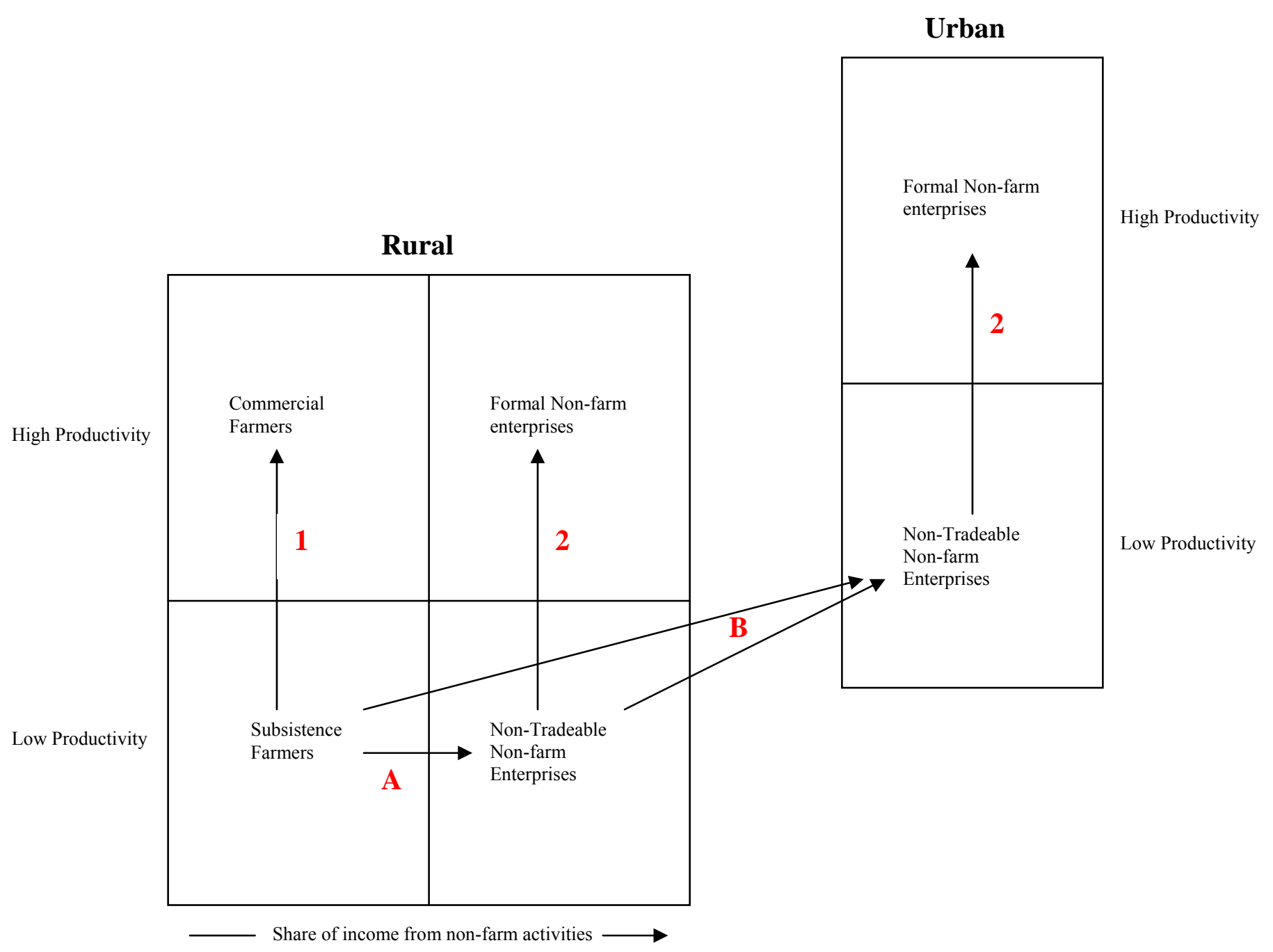


Complementing these two pathways, there are two "transition phases" which individuals may go through to reach the second route out of poverty. The first is a shift out of subsistence agriculture towards petty trading and manufacturing, as well as local non-tradable service provision (Transition Path A). This corresponds to the long-term sectoral shift from agriculture to non-agricultural activities as countries develop. Similarly, rural-urban migration, which can come both from households currently engaged in low-productivity agriculture and those currently engaged in petty trade, manufacturing and services, corresponds to the shift in location of economic activity seen during the structural transformation (Transition Path B).

\section{LITERATURE REVIEW}

\section{Connecting the rural economy to poverty reduction: the general experience}

The most comprehensive literature on this broad topic has been on the role of agriculture in economic development and poverty reduction. The basic linkages connecting agriculture to overall economic growth were first articulated to a general economics audience by Lewis (1954) and Johnston-Mellor (1961). At a conceptual level, these linkages have long been part of the core of modern development theory and practice (Timmer, 1988; 2002; Tiffin and Irz, 2006). Establishing the empirical value of these linkages in different settings has been a cottage industry since the early 1970s (Byerlee, 1973; Mellor and Lele, 1973; King and Byerlee, 1978; Hazell and Roell, 1983; Haggblade, Hammer and Hazell; 1991, Hazell and Haggblade, 1993; Timmer, 1997; Delgado, Hopkins and Kelly, 1998; Fan, Hazell and Thorat, 2000; Fan, Zhang and Zhang, 2002; Fan, Thorat and Rao, 2004). Virtually all of these studies conclude that the "agriculture multiplier" is significantly greater than one, especially in relatively closed, "non-tradable" economies of the sort found in rural Africa, where the multiplier is often between 2 and 3. But even in the more open economies of Asia, where border prices can be reasonably stable in the face of significant changes in domestic agricultural output, the agriculture multiplier is close to 2 in the early stages of agricultural modernization when productivity gains are the fastest. Because economic growth usually has a direct impact on poverty, any contribution agriculture makes to speeding overall economic growth 
through these large multipliers will, in most circumstances, also directly contribute to reducing poverty (Dollar and Kraay, 2002; World Bank, 2004a).

A related literature on the role of non-farm enterprises as engines of rural development, income growth, and poverty reduction has grown rapidly in the past decade (Mellor, 2000; Foster and Rosenzweig, 2004; Lanjouw and Lanjouw, 2001; Datt and Ravallion 1998, Ravallion and Datt, 1996, 1998, 2002; Haggblade, Hazell and Reardon, 2002). A key question addressed in this literature is whether non-farm enterprises are predominantly a low productivity supplementary activity which households undertake to diversify their income sources and insure against shocks to their agricultural income, which are important roles for the rural poor. The more promising hope, however, is that rural non-farm enterprises are potentially a source of growth and poverty alleviation in rural areas. Most of the literature suggests that non-farm activities fulfil both important functions.

These two literatures are bridged in a broader literature which attempts to understand the nature of pro-poor growth, which inevitably must encompass the rural poor and their potential pathways out of poverty (Ravallion 2004, World Bank, 2004a, 2006b). One theme of this literature argues that empirically, growth originating in the agricultural sector has tended to be more "pro-poor" than growth originating from the industrial or service sectors (Mellor, 1976; Ravallion and Datt, 1996; Ravallion and Chen, 2004; Timmer, 2002). Indeed, agricultural growth has often been an important ingredient in the formula that connects economic growth to the poor (Ravallion and Huppi, 1991; Ravallion and Datt, 1996; Ravallion and Chen, 2004; Sumarto and Suryahadi, 2003; Fan, Zhang and Zhang, 2004; Fan, Thorat and Rao, 2004; Timmer, 1997, 2004). New agricultural technologies that improve farm productivity strengthen this connection. Separate reviews by Thirtle, et al. (2003) and by Majid (2004) confirm the strong empirical link between higher agricultural productivity and poverty reduction.

One explanation for why agricultural productivity gains stimulate more rapid and pro-poor economic growth than urban-based growth is provided by Mellor's model of agricultural growth, rural employment and poverty reduction. This model emphasizes the role of the rural non-tradable sector in pulling underemployed workers out of agriculture into the non-agricultural rural economy. The Mellor model explicitly integrates 
manufactured export performance (the source of much dynamism in East Asia's economies since the 1960s) and the non-tradable sector in the rural economy (which includes a wide array of local agro-processing) to explain subsequent reductions in poverty. This model, drawing on Mellor's earlier work in India (Mellor, 1976) and more recently in Egypt (Mellor, 2000), explains why countries with substantial agricultural sectors that experienced rapid growth from labor-intensive manufactured exports had such good records of overall economic growth and poverty reduction.

\section{Connecting the rural economy to poverty reduction: the Asian experience}

Most of the four Asian country studies for the World Bank's recent study of propoor growth bear out the importance of agricultural growth for poverty reduction (Besley and Cord, 2006). For example, the Indonesian case study (Timmer, 2006) argues that conscious policy stimulus to agriculture was the key to the country's 30-year record of rapid, pro-poor growth (from 1967 to 1997), and that the model of smallholder agricultural development used by Indonesia is quite general. The Indonesian model is explicitly set in the broader historical literature on the role of agriculture and economic development that has been generated by successful countries not burdened with highly skewed land distributions as a starting point for their development (Johnston and Mellor, 1961; Hayami and Ruttan, 1985, Timmer, 1988, 2002).

However, the Bangladesh case study (B. Sen, Mujeri and Shahabuddin, 2006) and the Vietnam case study (Klump, 2006) each argue that agriculture played a large and crucial role in poverty reduction, but for highly idiosyncratic reasons based on unique initial conditions and domestic institutions. Thus they argue that agriculture was important to pro-poor growth in both countries, but that the role cannot be generalized to other countries.

In a separate study, Ravallion and Chen (2004) report that nearly all of the remarkable reduction in poverty in China between 1980 and 2001 was the result of agricultural growth specifically and diversified rural economic growth more broadly. They can find very little impact from growth in urban industrial and service sectors on reductions in the headcount poverty index (or the poverty gap or squared poverty gap). 
However, not all studies find agriculture to be the dominant force in poverty reduction. Controversially, the Indian case study by Besley, Burgess and Esteve-Volart (2006) argues on the basis of an enormously rich data set that agriculture has played a minimal role at best in India's reduction of poverty, directly contradicting earlier findings by Ravallion and Datt (1996, 1998, 2002). These results are missing an important part of the historical story. The analysis by Smith and Urey (2002) of the relationship between agricultural growth and poverty reduction in India since 1950 shows very clearly the important investments and policy attention to reaching India's rural poor through institutional and technical change in agriculture. This policy attention before the Green Revolution established an environment in which the new technologies could have widespread impact on both the rural and urban poor.

The second pathway out of poverty in Figure 1 is productivity growth in the nonfarm sector. All four of the Asian country studies mentioned above as well as the Ravallion-Chen study of China, note that the rural non-farm economy has been (or in the case of Vietnam, could be) an important mechanism for connecting the poor to economic growth. The growing size and, in many countries, faster growth of the rural non-farm sector, implies that this may be a pathway out of poverty of growing importance in the future. However, this depends on the nature of the rural non-farm sector.

Lanjouw and Lanjouw (2001) argue that rural non-farm enterprises are likely to be pro-poor, as they tend to use factors of production at their real opportunity costs to the economy, so they are often labor-intensive in nature, reducing underemployment, help smooth income seasonally and bid up local wages. Additionally, small and medium enterprises generate more employment per unit of capital than big firms; in general, wages in the non-farm sector are higher than in agriculture, so the low productivity residual activities do not seem to dominate this sector. Furthermore, they often produce low quality goods that are consumed by the poor, which benefit by obtaining local goods at lower prices, rather than expensive imports. The non-farm sector seems to be mostly inequality reducing, as it might be the only possibility for low-skilled workers to increase their incomes and to acquire non-agricultural skills from on-the-job experience. ${ }^{4}$

\footnotetext{
${ }^{4}$ See also the reviews of the rural non-farm sector in Bangladesh (World Bank, 2004b), Indonesia (World Bank, 2006a) and a multi-country synthesis (World Bank, 2006c).
} 
The dichotomy in the literature about whether agriculture or non-agricultural growth has been most effective for poverty reduction reflects to some extent the lack of a multi-sectoral or general equilibrium approach to the issue. For example, Larson and Mundlak (1997) show that across countries the pace of inter-sectoral labor migration is determined by the magnitude of the difference in average incomes in farm and non-farm sectors. As labor leaves the agricultural sector, labor productivity in agriculture increases. Thus the very process of structural transformation in which agriculture plays a smaller and smaller role is in itself responsible for raising incomes and reducing poverty within the agricultural sector (see also Timmer, 1988).

Similarly, Foster and Rosenzweig (2004) model the rural economy as a threesector economy encompassing agriculture, non-farm non-tradable goods and services and non-farm tradable goods. Income growth is realized in two main ways: either by the increase in agricultural productivity due to technological change or by increasing urban or world demand for manufactured goods produced in rural areas. So both sources of productivity growth, agriculture and increased non-farm activities, can raise income and alleviate poverty. The main prediction of the model is that increased demand for manufactured goods can be the most pro-poor driver, as it both raises income and reduces local and spatial inequality. Empirically they also show, using panel data from India, those regions with the slowest growth in high yielding varieties of crops experienced the greatest increase in the rural non-farm tradable sector. This is because capital is mobile and seeks low wage opportunities in the agriculturally poorer regions. In other words, those rural areas which did not manage to raise incomes due to agricultural productivity increases found their productivity growth in the non-farm sector. This suggests that the natural and institutional factors that determine agricultural productivity growth also determine whether agriculture or the non-farm sector will be the principal pathways out of poverty.

Datt and Ravallion (1998) report compatible results. They confirm empirically that the main sources of poverty reduction in Indian states were agricultural productivity growth or divergence from the trend in non-farm output growth. But the initial endowment of human and physical infrastructure is found to be a crucial precondition for long-run impact on poverty reduction in India, as they can be seen as a prerequisite for 
the success of non-farm enterprises. Their findings would suggest that a policy focus on agricultural productivity growth should alleviate poverty across the board as long as nonfarm enterprise constraints from infrastructure and human capital are mitigated. However, it might be harder to raise agricultural productivity growth in certain regions of the world than it is to alleviate the constraints facing non-farm enterprises. ${ }^{5}$

In summary, the literature suggests that agricultural growth has had an important role in poverty reduction in many countries. However, with more open trade possibilities, low prices for staple cereals in world markets, and population growth slowing, the importance of agricultural growth for overall economic growth and poverty reduction is no longer so clear. Furthermore, in most developing countries rural non-farm output now accounts for roughly half of rural income. Despite the fact that some nonfarm activity is surely of the low-productivity insurance type (and important to the poor for that reason), it is equally clear that the rural non-farm sector often enjoys greater potential for growth in income than the agricultural counterpart. This is especially true for rural regions that enjoy high levels of physical infrastructure and human capital, as such regions can reach higher productivity levels due to effective demand for their goods and services.

Thus, whether the farm or the non-farm sector has been the most important pathway out of poverty is ultimately an empirical question, as is the relative importance of inter-sectoral transitions and rural-urban migration. The answer for any given country depends both on its factor endowments as well as its policy and institutional history. We therefore explore the empirical evidence about the pathways out of poverty for Indonesia over the last two decades.

\section{EVIDENCE ABOUT PATHWAYS OUT OF POVERTY}

To understand what have been the most important paths out of poverty it is necessary to know how many people there are in each of the cells of Figure 1, how many of them managed to move from one cell to the other, and by how much they improved

\footnotetext{
${ }^{5}$ Several recent studies explore the difficulties of improving growth in the rural non-farm sector by improving the rural investment climate - see World Bank (2006a) on Indonesia, Deininger, Jin and Sur forthcoming on Sri Lanka, and World Bank (2006c) for a cross-country review of the evidence.
} 
their welfare. Leaving aside the distinction between low and high productivity for the moment, Table 1 shows the numbers of people working in agriculture and outside of agriculture in both rural and urban areas in Indonesia.

The aggregate evidence from SUSENAS suggests a steady movement out of agriculture over the last 20 years. The share of workers in agriculture dropped from 54\% in 1982 to $45 \%$ in 2002. Moreover, the official data suggest an even more marked fall in the share of workers in rural non-agriculture; the major growth has been in the share of workers working outside agriculture in urban areas, which has more than doubled in 20 years.

Table 1. Employment in Agriculture and Non Agriculture, Indonesia

\begin{tabular}{|l|c|c|c|c|c|c|}
\hline \multirow{2}{*}{} & \multicolumn{2}{|c|}{1982} & \multicolumn{2}{c|}{1993} & \multicolumn{2}{c|}{2002} \\
\cline { 2 - 7 } & $\mathrm{N}(000)$ & $\%$ & $\mathrm{~N}(000)$ & $\%$ & $\mathrm{~N}(000)$ & $\%$ \\
\hline \hline Agriculture & 30,487 & 54.24 & 39,137 & 49.88 & 39,035 & 44.92 \\
Non Agriculture & 25,724 & 45.76 & 39,329 & 50.12 & 47,874 & 55.08 \\
Rural & 15,939 & 28.36 & 18,992 & 24.20 & 16,785 & 19.31 \\
Urban & 9,785 & 17.41 & 20,337 & 25.92 & 31,088 & 35.77 \\
& & & & & & \\
All sector & 56,211 & 100 & 78,466 & 100 & 86,909 & 100 \\
\hline
\end{tabular}

Source: Susenas, 1982, 1993, 2002

Note: exclude Aceh, Maluku, North Maluku and Papua. Employment is defined as self employed without help, self employed with help of householders/temporary workers, self employed with help of regular workers, employees and family workers with age 10 years and over (definition until 1997). Definition of employment since 1998 is the same as above, but persons 15 years and above.

However, it is important to recognize that many areas which were rural in 1982 and 1993, are now classified as urban. This is because the definition of "urban" used by the Central Statistic Bureau relates to the number of amenities available in an administrative village, the population density and the share of income coming from agriculture. All of these change over time, with the result that at least 10 percent of rural villages in 1993 had been reclassified as urban by 2002. This is illustrated in Figure 2 which shows the change in the share of employment in rural and urban areas and in agriculture and non-agricultural activities between 1993 and 2002. The rural/urban classification in 1993 is used to determine rural/urban status thus avoiding confusion 
between re-classification and migration. Individuals were classified as poor or non-poor based on the per capita household expenditure of their households in the respective years.

When the employment data are re-classified in this way, the share of the workforce employed in low-productivity agriculture (poor) dropped by 1.55 percentage points between 1993 and 2002. Moreover, the change in the share of the workforce classified as urban and non-poor actually declines by 0.91 percentage points (instead of increasing by 9.88 percentage points in the official "published" data).

Figure 2: Changes in Employment Shares, 1993 to 2002

\section{Urban}

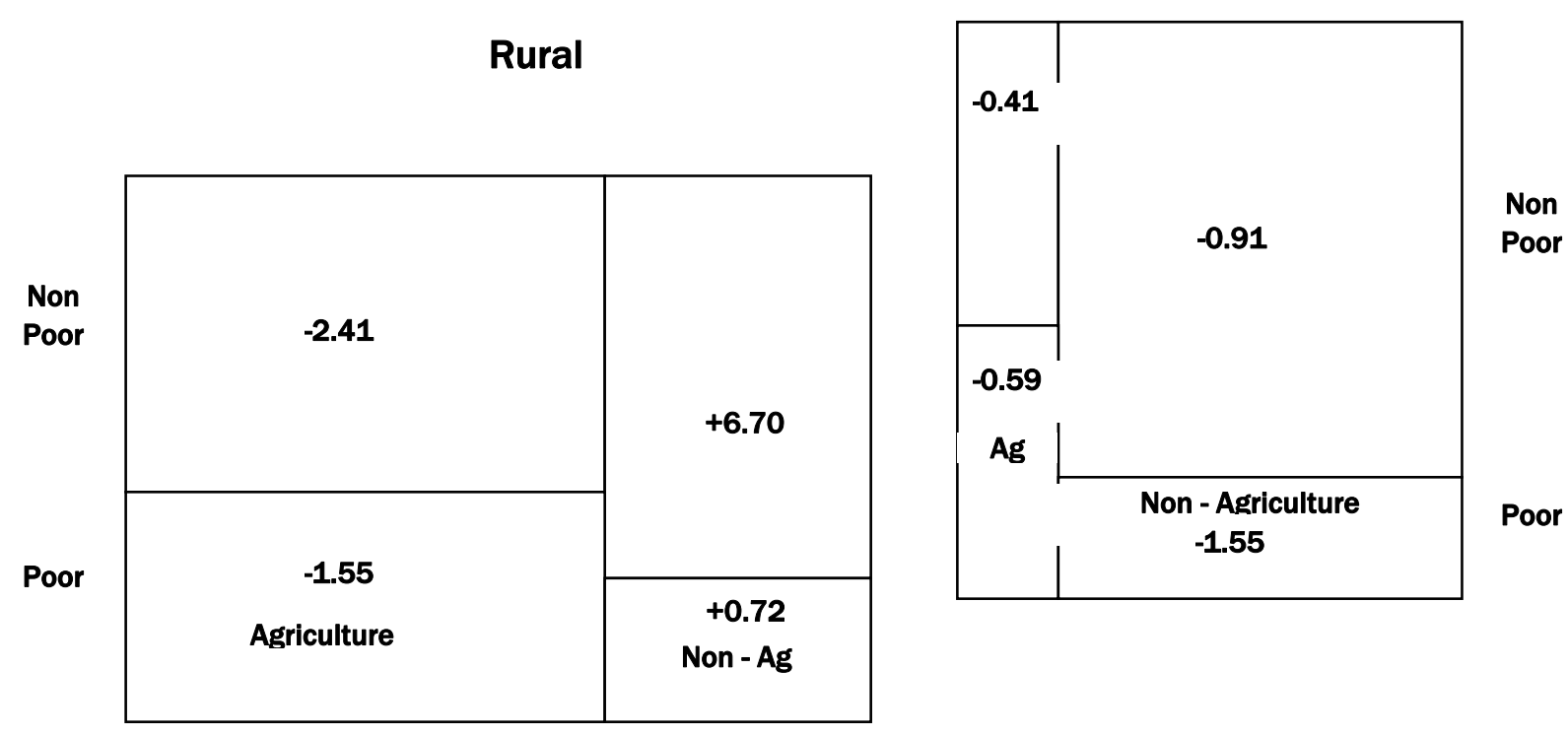

Note: The size of each rectangle is about proportionate to the numbers of workers employed in each category in 1993 . There were 78.5 million workers employed in 1993 and 86.9 million in 2002.

Source: Susenas 1993 and 2002.

Moreover, the reclassified data suggest that the growth of the rural non-farm sector has been an important route out of poverty with an increase of 6.7 percent in the share of workers who are non-poor and working outside of agriculture in rural areas. Thus, the role of rural non-farm sector in poverty reduction is hidden in the official data 
because it is the successful rural areas which are mostly likely to have become classified as urban during the course of the decade.

To get a sense of the role played by true rural-urban migration rather than urbanization, Table 2 shows estimates obtained from the inter-censal survey (Supas) in $1995 .{ }^{6}$ Only 2.8 percent of those individuals in rural villages in 1990 were living in urban villages in 1995. Moreover, the 3.6 million people who moved to urban villages between these two years were compensated in part by 1.8 million people who moved from urban to rural villages over the same period. Overall, around 5 percent of those in urban areas in 1995 had been living in rural areas five years previously. The role of "true" migration is certainly not trivial, but the much larger shifts in the shares of urban employment described above suggest that, overall, urbanization rather than rural-urban migration has been the dominant factor in changing the nature of activities undertaken by the poor and, therefore, their opportunities for finding a pathway out of poverty.

Table 2: True Rural-Urban Migration, 1990-1995

\begin{tabular}{rrrrr}
\hline & & \multicolumn{2}{c}{1995} & \\
\hline & & \multicolumn{1}{c}{ Rural } & \multicolumn{1}{c}{ Urban } & \multicolumn{1}{c}{ Total } \\
\hline 1990 & Rural & $122,037,729$ & $3,570,511$ & $125,608,240$ \\
& & 97.16 & 2.84 & 100 \\
& & 98.53 & 5.13 & 64.91 \\
& Urban & $1,823,701$ & $66,089,601$ & $67,913,302$ \\
& & 2.69 & 97.31 & 100 \\
& & 1.47 & 94.87 & 35.09 \\
& Total & $123,861,430$ & $69,660,112$ & $193,521,542$ \\
& & 64 & 36 & 100 \\
\hline & & 100 & 100 & 100 \\
\hline \multicolumn{2}{c}{ Source: Supas (1995) } & & &
\end{tabular}

While the above presents suggestive cross-sectional evidence about the numbers of people working in agriculture and non-agriculture in rural and urban areas in different years, these data do not show the numbers of people actually moving from agriculture to

\footnotetext{
6 "True" migration means that individuals actually physically moved from a village to somewhere else. Because the Supas survey asked about the respondent's address five years ago at the village level, it is possible to tell whether they actually moved village or not. The full Census only asked for this information at the district level making it impossible to tell from Census data whether they moved from rural or urban areas.
} 
non-agriculture. Thus, although these figures are suggestive about the pathways which may be the most important, they are not definitive--all that is shown is the net position rather than the actual flows themselves. It is impossible to observe directly the number of workers shifting sector with existing data from SUSENAS (although panel data will be available starting from 2004.

Furthermore, the lack of panel data does not allow us to identify the key characteristics that allowed individuals to increase their welfare by shifting sectors. In other words, the aggregate evidence tells us little about the micro-economic determinants, most notably education, location, etc., of sectoral employment shifts and implied welfare gains. For more definitive results on these topics a panel of data is needed, which is explored below.

\section{DATA}

To explore the microeconomic determinants of exiting poverty requires a panel data set over a reasonable length of time. Fortunately, the Indonesia Family Life Survey (IFLS) was first conducted in 1993 (IFLS1) and then again in 1997 (IFLS2), 1998 (IFLS2+) and finally in 2000 (IFLS3). For IFLS1, 7,224 households were interviewed with data collected on 22,000 individuals in those households. This sample is representative of about $83 \%$ of Indonesian population in 13 provinces. In 1993, IFLS did a face-to-face interview with the household head, the spouse, a sample of their children and a sample of other household members. In 1997, 94\% of IFLS1 households were reinterviewed consisting of all 1993 "main" respondents and all 1993 household members born before 1967. In 2000, IFLS managed to re-contact $95.3 \%$ of IFLS1 households interviewed: all 1993 "main” respondents, all 1993 household members born before 1967 and a sample of other 1993 household members. The sample size in 2000 was 10,400 households and 39,000 individuals.

The IFLS collects data at two levels. First, information is collected at the individual and household levels. This information consists of data on: consumption, income and assets; education, migration, and labor market outcomes; marriage, fertility and contraceptive use; health status, use of health care and health insurance; relationships among co resident and non co resident family members; processes underlying household 
decision-making; transfers among family members and inter-generational mobility; and participation in community activities. Secondly, the IFLS collects detailed information from the communities in which IFLS households are located including data on: physical and social environment, infrastructure, employment opportunities, food prices, access to health and educational facilities, and the quality and prices of services available at health and educational facilities. Unfortunately, the 1997 data on sectoral employment and migration were not published - thus for our analysis we will use only data from 1993 and 2000.

Our main aim is to understand to what extent sectoral and locational shifts determine movements out of poverty. For this reason, we restrict the panel used for our analysis to the individuals who were between the ages of 15 and 55 in 1993 and were working in both years. For these individuals we have an estimate of their income ${ }^{7}$, individual, household and community characteristics, as well as whether they shifted sector of employment and whether they moved location.

There are two main caveats associated with our choice of sample. First, the sample used for analysis does not account for the unemployed or for newcomers to the labor market after 1993. Thus if a key pathway out of poverty is the entrance into the labor force of people who were out of the labor force in 1993, we will not capture this effect. Similarly if individuals fall into poverty as a result of leaving the labor force (for example through death, illness or old age) this will not be observed. If the aim of our study was to capture all poverty dynamics, these would be serious omissions. However, our aim is to understand the extent to which changes in sector and location of existing workers drives poverty entrance and exits. Moreover, evidence from other developing countries suggest that, although entrance and exits from the labor force can be important, it is usually changes in the income status of existing working household members that drives most poverty entrance or exit (McCulloch and Cao, 2007).

\footnotetext{
${ }^{7}$ The IFLS collected data on individual income. This is calculated as the sum of gross profit, net profit, and wages. Combining these attributes too much income to individuals since, for some households, multiple members will contribute toward the profits from a household enterprise. We therefore tested for the possible biases which this might impact. In addition, calculations were done using individual income sources (wages, net profits, gross profits) to test the robustness of the results. The main findings were not altered substantially. The results are available on request.
} 
Second, we focus on the individual earnings of main household members. However, poverty is clearly a phenomenon that is experienced at the household level since, in most households, there is some pooling of resources. Thus, it is possible that the poverty transitions we observe may be due to changes in the incomes of household members that are not in our (or the IFLS) sample. However, although the IFLS sample did not interview every member of the household, the method used means that it is likely to have captured almost all the significant sources of income in the household.

Moreover, the vast majority of individuals in our sample are the sole or main income earner for their household, so changes in their earnings are likely to have a much larger impact on poverty transitions than changes in the earnings of other household members. In fact, the individual earning used for the analysis account on average for 70 and 67 percent of their actual specific total household income in 1993 and 2000 respectively. The corresponding median is even higher at 74 and 77 percent. Thus, the individual earnings in our sample account on average for 70 percent of household income. With these caveats in mind, our sample seems adequate for exploring the questions asked.

\section{POVERTY LINE}

The poverty line used for all the analysis below is derived from the 2000 BPS poverty line. ${ }^{8}$ For 1993 BPS also calculated a poverty line, but they used a methodology which is rather different than that used for the calculation of the 2000 poverty line. ${ }^{9}$ To ensure that the poverty line in 1993 represents the same purchasing power as that in 2000, the easiest approach would be to take the 2000 poverty line and deflate it using the provincial consumer price index (CPI) published by BPS. However, the published CPI uses a set of weights for its sub-indices which are heavily weighted in favor of wealthy consumers in urban areas. ${ }^{10}$ This bias in the CPI is particularly inappropriate for our analysis. In particular, since food prices rose more quickly than other prices over the period and the poor have a much higher share of their expenditure on food than the better

\footnotetext{
${ }^{8}$ This uses a variant of the Bidani and Ravallion (1993) methodology for calculating poverty lines

${ }^{9}$ The BPS methodology for the calculation of the poverty line changed in 1996.

${ }^{10}$ For example, the CPI share on food is $38 \%$ but the food share of the bottom quintile from Susenas is $66 \%$. A detailed discussion of this general problem is to be found in Grimm and Günther (2006)
} 
off, the published CPI understates the inflation experienced by the poor over this period. When this downward-biased CPI is used as a deflator, it produces a poverty line that is too high in 1993 and implausibly high measured levels of poverty. For this reason we reweighted the individual commodity group indices from the CPI published for each province using the expenditure shares for each commodity group of the bottom quintile in 1996. All subsequently reported real figures are deflated utilising the method described above.

\section{DESCRIPTIVE ANALYSIS}

Table 3 shows some of the key variables from the panel for 1993 and 2000. For the individual variables, the average age of the panel obviously rose as did the years of schooling, indicating that some panel participants completed further schooling in the intervening years. Interestingly, $62 \%$ of individuals worked in the non-farm sector, and this share did not change over the period. ${ }^{11}$ The mean real individual income in the sample rose between 1993 and 2000 by 15.2\%. However, as is often the case with income data, the mean is distorted by high outliers--the median income is a little more than half mean income in both years--but it also grew by a similar amount, 16.4\%, over the 7 year period. Working hours remained roughly constant, whilst there was a small decline in the share of individuals who were employees. It is important to remember that this 7 year period experienced considerable economic and political turmoil, and the economy had not recovered fully from the 1998 crisis when the 2000 interviews were held.

In the household variables, a substantial increase occurred in the share of households classified as living in urban areas between the two years. In 1993, 32\% of respondents lived in urban areas. In 2000, 40\% lived in urban areas, a striking change in only 7 years that is even more remarkable after considering the "reverse migration" of several million urban workers during the economic crisis in 1998.

\footnotetext{
${ }^{11}$ There were also significant changes in other sectors. The share of respondents in manufacturing declined from $14.3 \%$ to $10.8 \%$, whereas those working in social services rose from $13.6 \%$ to $19.6 \%$. These changes reflect the impact of the crisis and the growing informal service economy.
} 
Table 3: Descriptive Statistics for IFLS 1993 and 2000 Sample

\begin{tabular}{|c|c|c|c|c|}
\hline \begin{tabular}{|l} 
Variable \\
$\mathrm{N}=4797$
\end{tabular} & Mean in 1993 & $\begin{array}{c}\text { Median in } \\
1993\end{array}$ & Mean in 2000 & Median in 2000 \\
\hline Individual Variables & \multirow{7}{*}{$\begin{array}{c}37.3 \\
5.7 \\
0.62 \\
179,746 \\
213.5 \\
0.47\end{array}$} & \multirow{7}{*}{$\begin{array}{c}37 \\
6 \\
1 \\
93,145 \\
207.8 \\
0\end{array}$} & \multirow{7}{*}{$\begin{array}{c}45.2 \\
6.2 \\
0.62 \\
207,021 \\
211.7 \\
0.44\end{array}$} & \multirow{7}{*}{$\begin{array}{c}45 \\
6 \\
1 \\
108,453 \\
207.8 \\
0\end{array}$} \\
\hline Age & & & & \\
\hline Years of Schooling & & & & \\
\hline Non-farm & & & & \\
\hline Real individual income & & & & \\
\hline Working hours per month & & & & \\
\hline Employee dummy & & & & \\
\hline Household Variables & \multirow{6}{*}{$\begin{array}{l}0.32 \\
4.83 \\
0.70 \\
1.16 \\
0.91\end{array}$} & \multirow{6}{*}{$\begin{array}{l}0 \\
5 \\
1 \\
1 \\
1\end{array}$} & \multirow[b]{2}{*}{0.40} & \\
\hline Urban & & & & 0 \\
\hline Household Size & & & 5.81 & 6 \\
\hline Number of children $<5$ & & & 0.47 & 0 \\
\hline Number of children $<15$ & & & 1.06 & 1 \\
\hline Sex of household head & & & 0.92 & 1 \\
\hline $\begin{array}{l}\text { Real household expenditure per } \\
\text { capita }\end{array}$ & 78,956 & 50,276 & 80,944 & 55,673 \\
\hline Expenditure Poverty & 0.28 & 0 & 0.24 & 0 \\
\hline
\end{tabular}

Note: Sample is individuals between the age of 15-55 in 1993 and earning income in 1993. All summary statistics calculated using individual probability weights for 1993 and 2000 respectively. Real income and expenditure variables in 1996 Rupiah per month.

Demographic changes are also clearly illustrated: the average household size increases by one over the period of the panel with a shift towards more adults in the typical household as the children grow up. Households remain overwhelmingly maleheaded in both periods. Interestingly and puzzling, the growth in individual incomes of the panel members is not reflected in similarly high growth in the expenditures of the households from which they come. Mean real expenditure barely rose over the period, but what growth there was took place at the bottom end of the distribution, with the median per capita expenditure rising by $10.7 \%$. As a result of the steepness of the distribution near the poverty line, this relatively modest increase in expenditure resulted in a significant fall in poverty from $27.7 \%$ to $23.6 \% .^{12}$

\footnotetext{
${ }^{12}$ Note that the 2000 figure is similar to the official poverty figure from BPS for 2000 , but the 1993 figure is much higher. This is because we are comparing "like with like" by expressing both the 2000 poverty line and the income figures in 1996 prices. The official figure uses a poverty line with a completely different methodology, as noted earlier.
} 


\section{INCOME GROWTH}

With the IFLS panel it is possible to calculate directly the income growth for individuals who were working in particular sectors or regions. Table 4 shows the median income growth for individuals according to whether they lived in rural or urban areas and whether they worked in agriculture or outside of agriculture for 1993 and 2000. Table 4 shows an intriguing story of how income and income growth are associated with sectoral transition and rural-urban migration. First, the dramatic impact of both urban location and work outside of agriculture is evident: agricultural workers earn about half the income of those working outside agriculture in both rural and urban areas; similarly rural workers (whether farm or non-farm) earn little more than half the income of workers in the same sector in urban areas.

Next, consider how the typical worker in each group fared. The vast majority of rural farm workers in 1993 continued to be rural farm workers in 2000 and saw their real incomes decline by $11 \%$. Almost all of those who moved out of farming in rural areas did so by moving to non-farm activities in rural areas; these individuals saw their real incomes rise by almost a third. Very few rural agricultural workers moved to urban areas, so we do not place any confidence on the income growth figures for these transitions. However, we note that real income fell by 7\% between 1993 and 2000 for this poorest category of worker, with only those that shifted out of agriculture managing to increase their incomes significantly. 
Table 4: Income Growth Transitions by Rural, Urban and Sector 1993-2000

\begin{tabular}{|c|c|c|c|c|c|c|c|c|c|c|c|c|c|}
\hline & & & \multirow[b]{3}{*}{$\begin{array}{l}\text { Starting } \\
\text { income }\end{array}$} & \multirow[b]{3}{*}{ \#,Obs } & \multicolumn{9}{|c|}{2000} \\
\hline & & & & & \multicolumn{4}{|c|}{ Rural } & \multicolumn{4}{|c|}{ Urban } & \multirow{2}{*}{$\begin{array}{r}\text { Average } \\
\text { Ending } \\
\text { income }\end{array}$} \\
\hline & & & & & Farm & $\begin{array}{r}\# \\
\text { Obs }\end{array}$ & Nonfarm & $\begin{array}{r}\# \\
\text { Obs } \\
\end{array}$ & Farm & $\begin{array}{r}\#, \\
\text { Obs } \\
\end{array}$ & Nonfarm & \# Obs & \\
\hline & Rural & Farm & 48,470 & 1,590 & 40,660 & 1,268 & 78,519 & 274 & 22,305 & 31 & 107,177 & 17 & 44,868 \\
\hline & & & & & $-11.2 \%$ & & $31.1 \%$ & & $-56.4 \%$ & & $116.0 \%$ & & $-7.4 \%$ \\
\hline & & Nonfarm & 103,792 & 1,415 & 50,006 & 329 & 121,182 & 984 & 49,788 & 18 & 150,425 & 84 & 109,966 \\
\hline \multirow[t]{6}{*}{1993} & & & & & $-37.4 \%$ & & $11.0 \%$ & & $-40.0 \%$ & & $-9.5 \%$ & & $5.9 \%$ \\
\hline & Urban & Farm & 90,049 & 293 & 101,827 & 52 & 118,379 & 15 & 79,019 & 143 & 93,485 & 83 & 92,595 \\
\hline & & & & & $-15.4 \%$ & & $-22.2 \%$ & & $4.0 \%$ & & $8.8 \%$ & & $2.8 \%$ \\
\hline & & Nonfarm & 192,893 & 2,220 & 0 & 24 & 269,483 & 109 & 90,356 & 111 & 176,623 & 1,976 & 176,623 \\
\hline & & & & & $-100.0 \%$ & & $28.3 \%$ & & $-32.0 \%$ & & $-6.7 \%$ & & $-8.4 \%$ \\
\hline & All & & 95,904 & 5,518 & & 1,673 & & 1,382 & & 303 & & 2,160 & 107,875 \\
\hline
\end{tabular}

Note: Data are for individuals who were aged 15-55 in 1993 and were working in both years. Income figures are median monthly income in Rupiah in 1996 prices. Starting income figures are for 1993; all other income figures are for 2000. Income values and percentage changes in each cell represent the median incomes and percentage change in income of those individuals who made that transition. For example, the real income of the median rural agricultural worker that moved into non-agricultural activities in rural areas increased by $31 \%$, ending at Rp 78,519/month in 2000 . 
Workers who were already working outside agriculture in rural areas in 1993 were already much better off than their agricultural counterparts. Around $70 \%$ of these workers stayed in the same sector, seeing their incomes rise by $11 \%$ over the period. However, more than a fifth of these workers fell back into the agricultural sector and experienced a sharp reduction in their real incomes as a result. By contrast a small number managed to obtain non-farm work in urban areas. In fact, these workers did not fare particularly well, as their incomes fell by $9.5 \%$, but it is worth noting that those that managed to migrate to non-farm jobs in urban areas started out with incomes $60 \%$ higher than the median income for rural non-farm workers in 1993. The handful of individuals who found work in the agricultural sector in urban areas saw their incomes collapse, but again we treat this result with caution given the very small number of individuals involved.

Finally, the majority of the richest group, urban non-farm workers, stayed in this category and experienced a 7\% fall in their real incomes, probably associated with the economic crisis of the late 1990s. An unlucky 5\% of this group shifted to urban agricultural activities and saw their income fall by $32 \%$. A further $5 \%$ shifted back into rural areas while staying in non-agricultural activities. This group saw its income rise by $28 \%^{13}$.

Overall, how should we interpret these results? Three themes emerge. First, for the poorest, who are mostly employed in rural agriculture, getting out of agriculture was key to increasing their incomes. Only a handful of these individuals were able to migrate to urban areas, but almost a fifth left agriculture and in doing so substantially increased their incomes. Conversely, for those that had already left agriculture, moving back into agriculture was a sign of distress; all shifts back into agriculture from non-agricultural employment were associated with major income collapses, an outcome consistent with the drastic impact of the economic crisis.

Second, most of those who migrated to non-farm jobs in urban areas were already doing non-agricultural jobs in rural areas and tended to be among the better off non-farm

\footnotetext{
${ }^{13}$ A handful of others shifted back into rural agriculture - by coincidence all of these individuals report zero income in 2000 , but once again we interpret this result with caution given the small numbers involved.
} 
rural workers. But only $6 \%$ of rural non-farm workers managed to move to urban areas whilst almost a quarter fell back into agriculture.

Third, movements from urban non-farm employment to rural non-farm employment appear not to be associated with distress. This suggests that these better off workers may move back to rural areas voluntarily for the purpose of investment in their home areas.

\section{POVERTY TRANSITIONS}

The income growth table shows what happened to incomes. But income growth does not necessarily translate into movements in and out of poverty. To evaluate these movements, Table 5 shows a detailed poverty transition matrix between 1993 and 2000, disaggregated by rural and urban as well as agricultural and non-agriculture. The poverty of individuals is, of course, determined by the level of welfare of their whole households. We therefore determine the poverty status of individuals who were aged between 15 and 55 in 1993 and were earning income by whether the per capita expenditure of their households fell above or below the poverty line.

Although the IFLS data are not entirely representative of the Indonesian population, the 5308 workers tracked in Table 5 do represent basic Indonesian poverty patterns reasonably faithfully. Rural poverty made up 74.9 percent of total poverty in 1993 in the unweighted IFLS data, compared with 74.0 percent in the 1993 Susenas data. Analysis of how these 5308 workers fared between 1993 and 2000 should provide very useful insights into the dynamics of poverty in Indonesia. 
Table 5: Poverty Transition Matrix, 1993 to 2000, from IFLS Panel Data (raw numbers of individuals, not weighted)

\begin{tabular}{|c|c|c|c|c|c|c|c|c|c|c|c|c|}
\hline & & & & & \multicolumn{8}{|c|}{2000} \\
\hline & & & & & \multicolumn{4}{|c|}{ Poor } & \multicolumn{4}{|c|}{ Non Poor } \\
\hline & & & & & \multicolumn{2}{|c|}{ Rural } & \multicolumn{2}{|c|}{ Urban } & \multicolumn{2}{|c|}{ Rural } & \multicolumn{2}{|c|}{ Urban } \\
\hline & & & & $\begin{array}{c}\# \\
\text { individuals } \\
\end{array}$ & Agriculture & $\begin{array}{c}\text { Non } \\
\text { Agriculture }\end{array}$ & Agriculture & $\begin{array}{c}\text { Non } \\
\text { Agriculture }\end{array}$ & Agriculture & $\begin{array}{c}\text { Non } \\
\text { Agriculture } \\
\end{array}$ & Agriculture & $\begin{array}{c}\text { Non } \\
\text { Agriculture }\end{array}$ \\
\hline \multirow{8}{*}{ 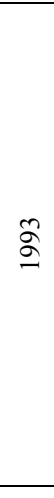 } & \multirow{4}{*}{ ڤั̊ } & \multirow[b]{2}{*}{ Rural } & Agriculture & 713 & 276 & 41 & 4 & 3 & 307 & 68 & 8 & 6 \\
\hline & & & $\begin{array}{l}\text { Non } \\
\text { Agriculture }\end{array}$ & 375 & 69 & 68 & 7 & 10 & 51 & 151 & 1 & 18 \\
\hline & & \multirow{2}{*}{ Urban } & Agriculture & 69 & 2 & 0 & 25 & 9 & 3 & 4 & 14 & 12 \\
\hline & & & $\begin{array}{l}\text { Non } \\
\text { Agriculture }\end{array}$ & 296 & 0 & 2 & 16 & 132 & 0 & 4 & 8 & 134 \\
\hline & \multirow{4}{*}{ 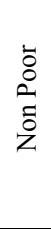 } & \multirow[t]{2}{*}{ Rural } & Agriculture & 1,053 & 162 & 38 & 3 & 0 & 648 & 174 & 19 & 9 \\
\hline & & & $\begin{array}{l}\text { Non } \\
\text { Agriculture }\end{array}$ & 1,389 & 61 & 117 & 0 & 23 & 238 & 864 & 17 & 69 \\
\hline & & \multirow[b]{2}{*}{ Urban } & Agriculture & 112 & 3 & 0 & 13 & 7 & 23 & 6 & 33 & 27 \\
\hline & & & $\begin{array}{l}\text { Non } \\
\text { Agriculture }\end{array}$ & 1,301 & 4 & 4 & 9 & 148 & 16 & 69 & 42 & 1009 \\
\hline & & & Total & 5,308 & 577 & 270 & 77 & 332 & 1,286 & 1,340 & 142 & 1,284 \\
\hline
\end{tabular}

Note: Data are numbers of individuals in the category in 1993 who end up in the 2000 category. The individuals are those who were aged 15-55 in 1993 and were working. 
Figure 3 shows some indication of the exquisite detail in the IFLS data. Not only is it possible to replicate the net flows from, for example, "poor, rural, agriculture" to "non-poor, rural, agriculture" as in Figure 2, it is also possible to track the movements of the actual individuals who make up those flows. The central panels in Figure 3 replicate the net flows in Figure 2, and tell reasonably consistent stories. More of the action in the IFLS data comes from productivity gains in agriculture, with the rural, non-farm economy actually losing workers. There is a modest gain in urban employment, although in net more of that gain is in urban agriculture than in non-agriculture, reflecting the impact of the economic crisis, which was still a major factor in 2000.

The power of panel data is revealed by taking apart these net flows, interesting as they are, and tracking the individuals who come and go from each cell. The IFLS data reveal astonishing mobility of individuals across cells. The example picked in Figure 3, the cell representing workers who started and ended as poor, rural and agricultural, is especially revealing. In net, 2.5 percent of the total sample of workers tracked left this cell between 1993 and 2000, exiting rural, agricultural poverty. But only 276 of the original 713 workers in this category in 1993 remained there in 2000. Another 301 individuals joined them from other categories: rural, agricultural but non-poor in 1993 (162), rural, non-agricultural and poor in 1993 (69) and rural, non-agricultural and nonpoor (61). According to Table 5 (showing actual numbers of individuals) and Figure 3 (which shows the share of these individuals in the total of 5308 who are tracked between 1993 and 2000), there are even 4 individuals who were urban, non-poor and nonagricultural in 1993 who ended up as poor, rural and agricultural in 2000! This particular number is small, but clearly the economic crisis fostered great mobility in the workforce.

The mobility out of rural, agricultural poverty between 1993 and 2000 is just as striking. Of the 713 workers who started in this category, 307 exited poverty by improving their agricultural productivity and 68 exited poverty by moving to the rural non-agricultural sector (41 remained poor after this move). Only 21 poor rural farmers moved to urban areas. 
Figure 3 Poverty transition matrix, 1993 to 2000, IFLS panel data, unweighted

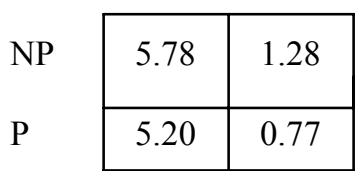

Ag Nag

Nag

\begin{tabular}{|l|l|}
\hline 0.15 & 0.11 \\
\hline 0.08 & 0.06 \\
\hline
\end{tabular}

Ag Nag

Where they went...

[Percent (out of 5308 workers in total) of the 713 individuals who started as rural, poor agriculture]

Non-

Poor

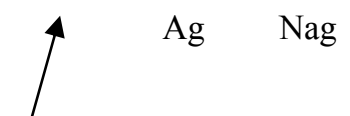

\section{URBAN}

\begin{tabular}{|c|c|}
\hline $\begin{array}{c}2.1->2.7 \\
=+0.6\end{array}$ & $\begin{array}{c}24.5->24.2 \\
=-0.3\end{array}$ \\
\hline $\begin{array}{c}1.3->1.5 \\
=+0.2\end{array}$ & $\begin{array}{c}5.6->6.3 \\
=+0.7\end{array}$ \\
\hline
\end{tabular}

Agric. Non-Ag

Where they came from... [Percent (out of 5308 workers in total) of the 577 individuals who ended up as rural, poor agriculture]

\begin{tabular}{|c|c|c|}
\cline { 2 - 3 } $\mathrm{NP}$ & 3.05 & 1.15 \\
\cline { 2 - 3 } $\mathrm{P}$ & 5.20 & 1.30 \\
\hline \multicolumn{2}{|c|}{$\mathrm{Ag}$} & $\mathrm{Nag}$
\end{tabular}

\begin{tabular}{|l|l|}
\hline 0.06 & 0.08 \\
\hline 0.04 & 0.00 \\
\hline
\end{tabular}

The central tables show the percent of the total IFLS workers who were tracked between 1993 and 2000 (5308 in number). In each cell, the first number is the percent in that cell in 1993, with the arrow pointing to the number in that cell in 2000. The bottom number is then the net difference between 1993 and 2000, and thus this net number corresponds to similar numbers in Figure 2. But these are only net flows, and Table 5 actually permits the identification of which workers made up that net flow and where they came from and went. That is what the upper and lower cells show for just one of the net flows, for the rural, agricultural, poor. 
Three key lessons emerge from this descriptive analysis of the IFLS data:

\section{Improved productivity in agriculture is still an important route out of poverty:}

Most of the rural agricultural poor in this sample who exit poverty do so while staying in rural agriculture, which is a sharp contrast with the SUSENAS results from the 1993-2002 analysis. Over $80 \%$ of the poor rural farmers in the sample were still working in rural agriculture in 2000 , but more than half of the households from which they come still managed to exit from poverty. Most of the rest moved into non-agricultural activities in rural areas and, more often than not, out of poverty too. However, in agreement with the SUSENAS results, moving to urban areas was rare for this group - only 2.9 percent of those working as poor rural farmers in 1993 were working in urban areas in 2000. Based on SUSENAS data, just 44.6 percent of employed individuals in 2002 were primarily engaged in agriculture, but 61.3 percent of the poor and 56.9 percent of the "near poor" worked in agriculture. Raising agricultural productivity seems to be an effective way of reaching these households.

\section{Rural non-agricultural activities can be a stepping stone out of poverty in rural}

areas: Individuals from poor rural households who worked off-farm in 1993 were more mobile than those working in agriculture. Less than a fifth stayed poor in rural non-agricultural activities - but overall they were equally likely to stay poor, as a similar number shifted back to agriculture while remaining poor. More than half escaped poverty while staying in rural areas - a similar rate to those who started poor in agriculture. Urban migration played a more important role for this group, but still a minor one - less than $10 \%$ of this group moved to urban areas, and only half of those that did so exited poverty. ${ }^{14}$ Still, this migration ratealmost 10 percent of poor, rural non-farm workers migrated to urban areas in just 7 years - is more than three times the rural-to-urban migration rate of poor farm workers (only 2.9 percent of poor farm workers moved to urban areas, and onethird of those remained in poverty). During the same period, 15.4 percent of poor,

\footnotetext{
14 Note that re-classifications are very rare $(3.26 \%)$ in this panel so that almost all the rural-urban movements observed involve actual physical movement of the person. This adds weight to the evidence that urbanization rather than rural-urban migration is the principle form of rural-urban transition.
} 
rural farmers moved to rural non-agricultural jobs and almost two-thirds of these exited poverty in the process. The potential for the non-farm rural economy to be a stepping stone out of poverty is clear. Here, the panel results add great emphasis to the SUSENAS-based analysis.

\section{Non-agricultural activities in urban areas may be somewhat more stable: As Table} 5 shows, 77.6 percent of the non-poor in this category remained non-poor, nonagricultural and in urban areas. At the same time, 44.6 percent of the urban nonagricultural poor remained in that category. Both rates of "stability" are the highest of the four categories. This stability may arise because earnings are much higher in urban areas, so the poor prefer to stay in the hope of a good job; or it may be difficult for poor urban workers to move or return to rural areas. The distinction should not be overdrawn, however, as 61.5 percent of the rural, agricultural non-poor remained in this category and 62.2 percent of the rural, nonagricultural non-poor had similar stability. Indeed, when agricultural and nonagricultural activities are combined, a common occurrence for households in rural areas, 78.0 percent of rural agricultural households and 79.3 percent of rural nonagricultural households (in 1993) remained stably out of poverty. Importantly, only the panel results can bring a clear picture of how much "churning" there is near the poverty line. Clearly, there is a small but significant probability of falling below that line for rural workers, whether farm or non-farm.

In summary, urbanization has been rapid, but only a small part is due to actual physical migration of workers and households. In rural areas, there is a gradual diversification of economic activities taking place, characterized by greater reliance on non-farm sources of income. This process of rural diversification reflects greater opportunities for growth in a dynamic non-farm economy than in agriculture per se, although increases in agricultural productivity have remained a very important path out of poverty, at least as judged from the panel data.

These results are only a glimpse into the power of panel data. Many of the transition paths described above are strongly influenced by the individual characteristics 
of workers, which are not considered above. The following section explores the importance of these characteristics (as well as the characteristics of the families from which they come) on income growth and movements out of poverty.

\section{MICRO DETERMINANTS OF INCOME AND POVERTY TRANSITIONS}

\section{THE DETERMINANTS OF INCOME AND POVERTY LEVELS}

In order to identify the determinants of income mobility it is necessary to follow individuals and their earnings over time, which can only be accomplished using panel data. To start, we follow the common methodology and regress log real personal income using OLS on multiple explanatory variables to identify correlates of the level of real income in 1993 and 2000 respectively. Despite the well known methodological limitations of this approach, the OLS level regression is still a useful way of gaining a better understanding of factors affecting real income levels. Table 6 shows the results of log real income in 1993 and 2000 regressed on a combination of individual, household, geographic and employment characteristics. We also run a Logit regression of the probability of being poor using the same explanatory variables as the OLS regression (Table 7). As mentioned above, our sample is restricted to individuals who were between 15 and 55 in 1993 and earned an income; their poverty status is determined by whether the per capita expenditure of their households fell above or below the poverty line.

Several variables are strongly associated with log real income. Real income increases with age but at a declining rate. A person who was one year older in 1993 received on average 9 percent more income and 10 percent in 2000 (due to the aging of the panel). Male income is $44 \%$ higher than female income in 1993, even when age and education are taken into account. This gap widens as the panel ages--younger women marry and have children, reducing their individual income. Years of schooling, as expected, have a strong effect with each additional year of schooling raising the level of real income by 8.7 percent in 1993.

Household-level variables also have an impact. Workers who were part of a household gain on average 7.3 percent more income in 1993 for each additional family 
Table 6: The Determinants of Log Real Income in 1993 and 2000

\begin{tabular}{|c|c|c|c|c|}
\hline & 1993 & 1993 & 2000 & $200 \odot$ \\
\hline Age & $\begin{array}{l}0.096 \\
(5.78) * *\end{array}$ & $\begin{array}{l}0.092 \\
(5.44) * *\end{array}$ & $\begin{array}{l}0.103 \\
(5.58) * *\end{array}$ & $\begin{array}{l}0.098 \\
(5.28) * *\end{array}$ \\
\hline Age squared & $\begin{array}{l}-0.001 \\
(5.47)^{* *}\end{array}$ & $\begin{array}{l}-0.001 \\
(5.22)^{* *}\end{array}$ & $\begin{array}{l}-0.001 \\
(5.85)^{* *}\end{array}$ & $\begin{array}{l}-0.001 \\
(5.61)^{* *}\end{array}$ \\
\hline Sex & $\begin{array}{l}0.433 \\
(11.14) * *\end{array}$ & $\begin{array}{l}0.440 \\
(10.83) * *\end{array}$ & $\begin{array}{l}0.596 \\
(15.58) * *\end{array}$ & $\begin{array}{l}0.607 \\
(15.22) * *\end{array}$ \\
\hline \multirow[t]{2}{*}{$\begin{array}{l}\text { Working hours } \\
\text { per month }\end{array}$} & 0.002 & 0.002 & 0.001 & 0.001 \\
\hline & $(12.21) * *$ & $(12.16)$ ** & $(6.70)^{* *}$ & $(6.87)^{\star *}$ \\
\hline \multirow[t]{2}{*}{$\begin{array}{l}\text { Wage income } \\
\text { dummy }\end{array}$} & 0.145 & 0.137 & -0.024 & -0.050 \\
\hline & $(4.13) * *$ & $(3.50) * *$ & $(0.67)$ & $(1.29)$ \\
\hline \multirow[t]{2}{*}{$\begin{array}{l}\text { Years of } \\
\text { schooling }\end{array}$} & $\odot .087$ & 0.082 & 0.103 & $\odot .097$ \\
\hline & $(20.27) * *$ & $(17.64) * *$ & $(25.71) * *$ & $(22.13)^{* *}$ \\
\hline \multirow{3}{*}{$\begin{array}{l}\text { Household size } \\
\text { Number of } \\
\text { Children < } 5\end{array}$} & $\begin{array}{l}0.073 \\
(4.86) * *\end{array}$ & $\begin{array}{l}0.074 \\
(4.94) * *\end{array}$ & $\begin{array}{l}0.058 \\
(4.52) * *\end{array}$ & $\begin{array}{l}0.057 \\
(4.50) * *\end{array}$ \\
\hline & -0.094 & -0.094 & -0.064 & -0.063 \\
\hline & $(3.7 \odot) * *$ & $(3.71)^{* *}$ & $(2.25)^{*}$ & $(2.20)^{*}$ \\
\hline \multirow[t]{2}{*}{$\begin{array}{l}\text { Number of } \\
\text { Children }<15\end{array}$} & -0.049 & -0.048 & -0.037 & -0.036 \\
\hline & $(2.66) * *$ & $(2.59) * *$ & $(2.09)^{*}$ & $(2.01)^{*}$ \\
\hline \multirow{2}{*}{$\begin{array}{l}\text { Number of Men } \\
\text { in hh }\end{array}$} & -0.043 & -0.045 & -0.038 & -0.036 \\
\hline & $(2.29)^{*}$ & $(2.39)^{*}$ & $(2.09)^{*}$ & $(1.99)^{*}$ \\
\hline Urban Dummy & $\begin{array}{l}0.248 \\
(7.02) * *\end{array}$ & $\begin{array}{l}0.251 \\
(7.14) \text { ** }\end{array}$ & $\begin{array}{l}0.055 \\
(1.49)\end{array}$ & $\begin{array}{l}0.068 \\
(1.82)\end{array}$ \\
\hline North Sumatra & $\begin{array}{l}-0.204 \\
(2.79)^{* *}\end{array}$ & $\begin{array}{l}-0.198 \\
(2.69)^{* *}\end{array}$ & $\begin{array}{l}-0.124 \\
(1.67)\end{array}$ & $\begin{array}{l}-0.102 \\
(1.36)\end{array}$ \\
\hline West Sumatra & $\begin{array}{l}-0.236 \\
(3.05)^{* *}\end{array}$ & $\begin{array}{l}-0.240 \\
(3.05)^{* *}\end{array}$ & $\begin{array}{l}-0.260 \\
(2.69)^{* *}\end{array}$ & $\begin{array}{l}-0.259 \\
(2.67)^{* *}\end{array}$ \\
\hline South Sumatra & $\begin{array}{l}-0.401 \\
(5.00)^{* *}\end{array}$ & $\begin{array}{l}-0.414 \\
(5.11)^{* *}\end{array}$ & $\begin{array}{l}-0.189 \\
(2.18)^{*}\end{array}$ & $\begin{array}{l}-0.184 \\
(2.09)^{*}\end{array}$ \\
\hline Lampung & $\begin{array}{l}-0.542 \\
(6.20)^{* *}\end{array}$ & $\begin{array}{l}-0.538 \\
(6.12)^{* *}\end{array}$ & $\begin{array}{l}-0.305 \\
(3.33)^{* *}\end{array}$ & $\begin{array}{l}-0.297 \\
(3.24) * *\end{array}$ \\
\hline West Java & $\begin{array}{l}-0.307 \\
(5.17)^{* *}\end{array}$ & $\begin{array}{l}-0.288 \\
(4.78)^{* *}\end{array}$ & $\begin{array}{l}-0.060 \\
(0.96)\end{array}$ & $\begin{array}{l}-0.054 \\
(0.85)\end{array}$ \\
\hline Central Java & $\begin{array}{l}-0.593 \\
(9.58)^{* *}\end{array}$ & $\begin{array}{l}-0.578 \\
(9.19)^{* *}\end{array}$ & $\begin{array}{l}-0.304 \\
(4.79)^{* *}\end{array}$ & $\begin{array}{l}-0.276 \\
(4.31)^{* *}\end{array}$ \\
\hline Di Yogyakarta & $\begin{array}{l}-0.700 \\
(9.83)^{* *}\end{array}$ & $\begin{array}{l}-0.690 \\
(9.78)^{* *}\end{array}$ & $\begin{array}{l}-0.472 \\
(6.21)^{* *}\end{array}$ & $\begin{array}{l}-0.456 \\
(6.01)^{* *}\end{array}$ \\
\hline East Java & $\begin{array}{l}-0.565 \\
(9.37)^{* *}\end{array}$ & $\begin{array}{l}-0.554 \\
(9.12)^{* *}\end{array}$ & $\begin{array}{l}-0.260 \\
(4.12)^{* *}\end{array}$ & $\begin{array}{l}-0.244 \\
(3.83)^{* *}\end{array}$ \\
\hline Bali & $\begin{array}{l}-0.196 \\
(2.83)^{* *}\end{array}$ & $\begin{array}{l}-0.208 \\
(2.98)^{* *}\end{array}$ & $\begin{array}{l}-0.149 \\
(1.91)\end{array}$ & $\begin{array}{l}-0.162 \\
(2.05)^{*}\end{array}$ \\
\hline \multirow{2}{*}{$\begin{array}{l}\text { West } \\
\text { NusaTenggara }\end{array}$} & -0.462 & -0.462 & -0.228 & -0.220 \\
\hline & $(5.36) * *$ & $(5.32) * *$ & $(3.02)^{* *}$ & $(2.91) * *$ \\
\hline $\begin{array}{l}\text { South } \\
\text { Kalimantan }\end{array}$ & 0.012 & -0.006 & -0.115 & -0.126 \\
\hline
\end{tabular}




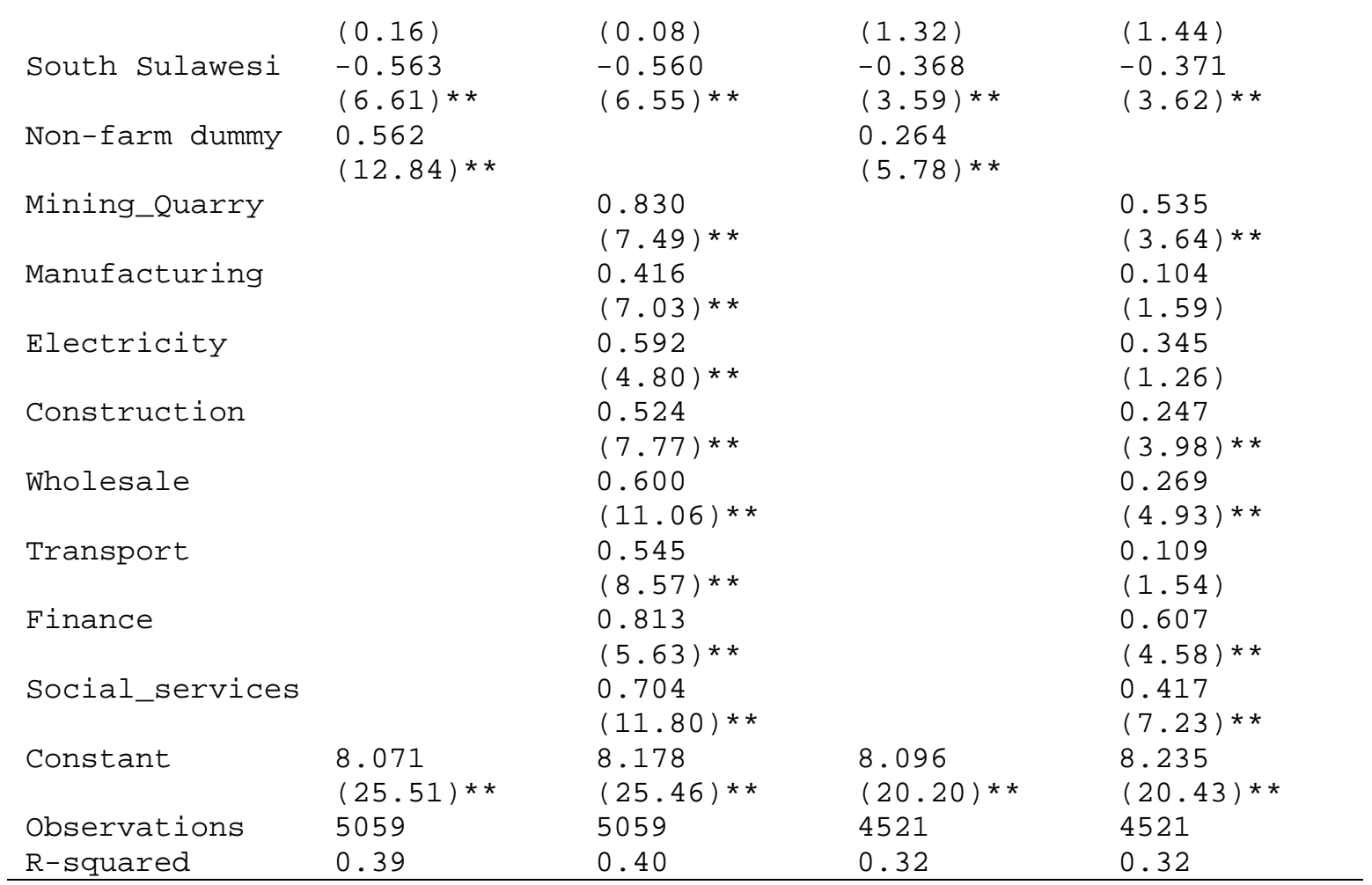

Robust $t$ statistics in parentheses

* significant at $5 \%$; * significant at $1 \%$ 
Table 7: Cross-Sectional Poverty Logit Regression

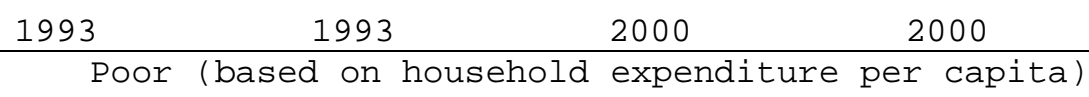

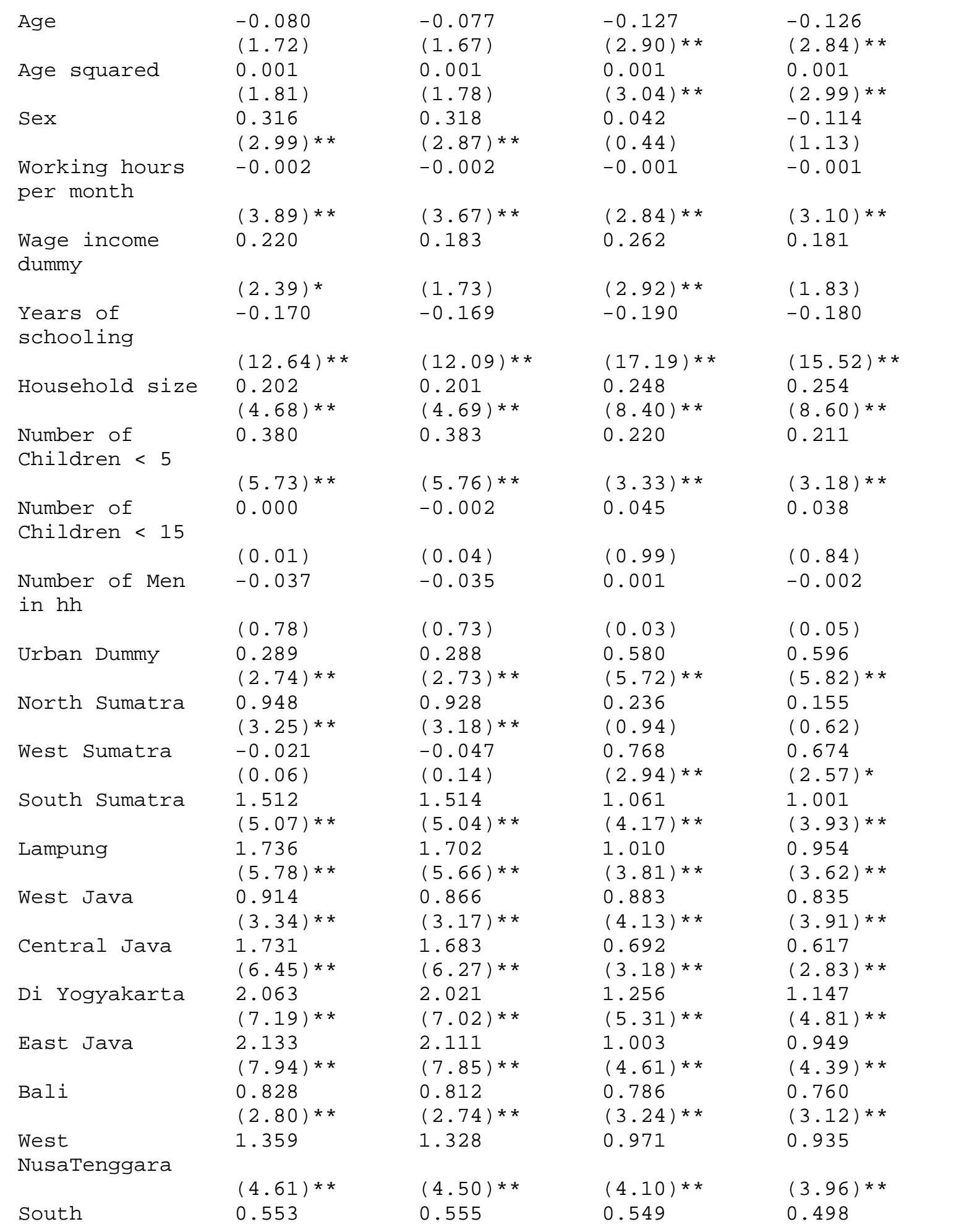




\begin{tabular}{|c|c|c|c|c|}
\hline \multicolumn{5}{|l|}{ Kalimantan } \\
\hline & $(1.75)$ & $(1.75)$ & $(2.06)^{*}$ & $(1.87)$ \\
\hline South Sulawesi & $\begin{array}{l}1.034 \\
(3.36) * *\end{array}$ & $\begin{array}{l}0.992 \\
(3.22) * *\end{array}$ & $\begin{array}{l}\odot .526 \\
(1.99) \text { * }\end{array}$ & $\begin{array}{l}0.451 \\
(1.70)\end{array}$ \\
\hline Non-farm dummy & $\begin{array}{l}-0.641 \\
(6.28)^{*}\end{array}$ & & $\begin{array}{l}-0.480 \\
(4.84)^{* *}\end{array}$ & \\
\hline Mining_Quarry & & $\begin{array}{l}-1.660 \\
(2.91)^{* *}\end{array}$ & & $\begin{array}{l}0.160 \\
(0.42)\end{array}$ \\
\hline Manufacturing & & $\begin{array}{l}-0.392 \\
(2.63)^{*}\end{array}$ & & $\begin{array}{l}-0.345 \\
(2.28)^{*}\end{array}$ \\
\hline Electricity & & $\begin{array}{l}-0.774 \\
(1.51)\end{array}$ & & $\begin{array}{l}-1.431 \\
(1.40)\end{array}$ \\
\hline Construction & & $\begin{array}{l}-0.416 \\
(2.00)\end{array}$ & & $\begin{array}{l}0.061 \\
(0.32)\end{array}$ \\
\hline Wholesale & & $\begin{array}{l}-0.740 \\
(5.50)^{*}\end{array}$ & & $\begin{array}{l}-0.779 \\
(5.92)\end{array}$ \\
\hline Transport & & $\begin{array}{l}-0.785 \\
(3.94)^{* *}\end{array}$ & & $\begin{array}{l}0.112 \\
(0.59)\end{array}$ \\
\hline Finance & & $\begin{array}{r}-0.840 \\
(1.20)\end{array}$ & & \\
\hline Social_services & & $\begin{array}{l}-0.723 \\
(3.55) * *\end{array}$ & & $\begin{array}{l}-0.805 \\
(5.27)^{*}\end{array}$ \\
\hline Constant & $\begin{array}{r}-1.020 \\
(1.09)\end{array}$ & $\begin{array}{r}-1.085 \\
(1.17)\end{array}$ & $\begin{array}{l}0.201 \\
(0.20)\end{array}$ & $\begin{array}{l}0.330 \\
(0.33)\end{array}$ \\
\hline Observations & 5227 & 5227 & 5010 & 4980 \\
\hline
\end{tabular}

Robust z statistics in parentheses

$*$ significant at 5\%; ** significant at $1 \%$ 
member. ${ }^{15}$ But having a larger number of children below the age of 5 seems to lower real income. The "number of children" effect cancels out the positive effect of household size, suggesting that any advantage of having a larger household is lost once one takes small children into account. Interestingly the number of men in a household affects average real income negatively. Having more adult males living in the same household may be an indication of poverty (reflected in low individual income) even if their presence boosts household income.

Geographical variables have an extremely strong impact on income. Individuals in urban areas in 1993 earned on average 25 percent more than similar workers in rural $\operatorname{areas}^{16}$, but this differential had fallen to 5.5 percent by 2000. This is consistent with rural income growth being much faster than urban income growth over this period because of the economic crisis. There are also wide variations between incomes in different provinces. Relative to Jakarta, incomes are lower in all provinces with the most pronounced income gaps in 1993 occurring in Yogyakarta, South Sulawesi, Lampung, Central Java, and East Java. This changed dramatically in 2000 as Jakarta was badly hit by the crisis, reducing the income disparity between it and the other provinces.

Economic and sectoral variables also have an influence. Deriving income predominantly from wages does appear to raise income slightly, but the effect turns negative and is not statistically significant in 2000. Working more hours also increases income, but the effect is rather small. By contrast there are large sectoral differences in income. Working primarily in the non-farm sector boosts real income in 1993 by 56.2 percent relative to agricultural activities, although this advantage declined to 26.4 percent in 2000. For specific sectors of employment there are large disparities relative to agriculture: Finance (81\%), Mining and Quarrying (83\%), and Social Services (70\%) display particularly large differentials. These differences were substantially reduced between 1993 and 2000 due to the poor performance of many of these sectors relative to agriculture over this period.

\footnotetext{
${ }^{15}$ This result is anomalous since usually larger households are associated with lower per capita incomes. It may result from the attribution of all profit income earned by family labor to the main earner in the household.

${ }^{16}$ This difference is likely to be overstated since nominal income is deflated by provincial CPI, which is based on prices in the province's main city.
} 
The results from the Logit poverty regressions confirm and strengthen the OLS regression results. Even though we determine the poverty status of the individual by the per capita expenditure of the household rather than by their individual incomes, these two concepts are strongly linked, particularly when the sample is restricted to income earners. Hence, as expected, being older and more educated reduces the chance of being poor. Larger households now increase the probability of being poor as does the number of children below the age of five. Being male increases the probability of being poor for our sample. This may be because the females in our sample are income earners and households in which the woman is also earning an income are likely to be better off than those in which only the male is earning. Interestingly, this positive probability disappeared in 2000, suggesting either that males managed to increase their earning situation considerably or that women lost out relatively more during the crisis.

Surprisingly, living in an urban area increases the probability of being poor, and this effect increases over time. Similarly, the probability of being poor is generally higher outside Jakarta, although this effect is reduced in 2000 due to the improving relative position of the provinces with respect to Jakarta. Employment outside of agriculture reduces the probability of being poor, particularly in the 1993 sample.

The level regressions above confirm many of the links expected from the literature between personal, household, sectoral and regional characteristics and level of income and poverty. However, they do not tell us much about the dynamics of income and poverty. For this we need to exploit the panel nature of the dataset to identify the determinants of income and poverty changes.

\section{THE DETERMINANTS OF INCOME AND POVERTY CHANGES}

To identify the determinants of income change we estimate a difference regression on both initial characteristics and changes in those characteristics. In particular we are interested to see if a change from the farm to the non-farm sector has an important impact upon income growth. In other words we estimate:

$$
\begin{aligned}
& d \ln y=\beta_{0}+\beta_{1} \cdot I N D C H A R S+\beta_{2} \cdot H H C H A R S+\beta_{3} \cdot G E O G+\beta_{4} \cdot S E C T O R+ \\
& \beta_{1}^{d} . d I N D C H A R S+\beta_{2}^{d} . d H H C H A R S+\beta_{3}^{d} . d G E O G+\beta_{4}^{d} . d S E C T O R+\varepsilon
\end{aligned}
$$


where INDCHARS is a vector of individual characteristics, HHCHARS is a set of household characteristics, GEOG is a set of geographical variables, and SECTOR is a set of sectoral variables; $\varepsilon$ is an error term and the prefix $d$ indicates changes. We are particularly interested in observing the size and sign of the dummies for changing sector. The results are shown in Table 8.

As is common in the growth regression literature, the log of real initial income has a negative coefficient, implying conditional income convergence. In fact, the data also show strong absolute convergence (Table 9) of income implying declining income inequality. ${ }^{17}$ Individuals who were older in 1993 tended to have higher growth rates, although the size of this effect declines with age. Male workers also experienced much higher income growth than female workers, but those whose income came from wages experienced slower growth consistent with the impact of the crisis on formal wages. People with higher working hours in 1993 also experienced slightly lower income growth and the expansion of working hours is also associated with slower growth implying that it indicates stress rather than success.

Individuals who were better educated in 1993 tended to have higher subsequent income growth (around 6\% higher growth per extra year of schooling). Households which were larger initially had faster income growth and growing households are also associated with higher income growth (although, of course, the causality here may run in the opposite direction). Having a large number of younger children is not only associated with lower income, but also with slower growth, although, as would be expected, increases in the number of young children are positively (but not statistically significantly) associated with growth. Having a larger number of men in the households is also associated with slower growth, although the effect is not statistically significant.

\footnotetext{
${ }^{17}$ This is also consistent with the results obtained by Fields et al (2003) showing declining inequality for Indonesia between 1993 and 1997, as well as results reported in the World Bank's Poverty Assessment for Indonesia (2006b).
} 
Table 8: Income Difference Regression 1993-2000

\begin{tabular}{|c|c|c|c|c|}
\hline & (1) & (2) & (3) & (4) \\
\hline Dependent variable & \multicolumn{4}{|c|}{ Change in log real income } \\
\hline Log Real Income 1993 & $\begin{array}{l}-0.623 \\
(23.32) * *\end{array}$ & $\begin{array}{l}-0.570 \\
(17.92) * *\end{array}$ & $\begin{array}{l}-0.632 \\
(23.64) * *\end{array}$ & $\begin{array}{l}-0.581 \\
(18.19) * *\end{array}$ \\
\hline Age & $\begin{array}{l}0.043 \\
(2.50) *\end{array}$ & $\begin{array}{l}0.043 \\
(2.48)^{*}\end{array}$ & $\begin{array}{l}\odot .040 \\
(2.38)^{*}\end{array}$ & $\begin{array}{l}\odot .040 \\
(2.37)^{*}\end{array}$ \\
\hline Age Squared & $\begin{array}{l}-0.001 \\
(2.96)^{* *}\end{array}$ & $\begin{array}{l}-0.001 \\
(2.94)^{* *}\end{array}$ & $\begin{array}{l}-0.001 \\
(2.91)^{* *}\end{array}$ & $\begin{array}{l}-0.001 \\
(2.90)^{* *}\end{array}$ \\
\hline Sex & $\begin{array}{l}0.446 \\
(9.85) * *\end{array}$ & $\begin{array}{l}0.443 \\
(9.82) * *\end{array}$ & $\begin{array}{l}0.481 \\
(10.19) * *\end{array}$ & $\begin{array}{l}0.478 \\
(10.17) * *\end{array}$ \\
\hline Working hours per month & $\begin{array}{l}-0.002 \\
(7.44)^{* *}\end{array}$ & $\begin{array}{l}-0.002 \\
(7.37) * *\end{array}$ & $\begin{array}{l}-0.002 \\
(7.31)^{* *}\end{array}$ & $\begin{array}{l}-0.002 \\
(7.24)^{* *}\end{array}$ \\
\hline $\begin{array}{l}\text { Change in Working hours per } \\
\text { month }\end{array}$ & -0.001 & -0.001 & -0.001 & -0.001 \\
\hline Wage Income Dummy & $\begin{array}{l}(5.98) * * \\
-0.032 \\
(0.78)\end{array}$ & $\begin{array}{l}(6.11)^{* *} \\
-0.028 \\
(0.71)\end{array}$ & $\begin{array}{l}(6.08) * * \\
-0.036 \\
(0.76)\end{array}$ & $\begin{array}{l}(6.21)^{* *} \\
-0.032 \\
(0.69)\end{array}$ \\
\hline Years of schooling & $\begin{array}{l}0.064 \\
(11.90) * *\end{array}$ & $\begin{array}{l}0.064 \\
(11.87)^{* *}\end{array}$ & $\begin{array}{l}\odot .057 \\
(10.00) * *\end{array}$ & $\begin{array}{l}0.057 \\
(9.99) * *\end{array}$ \\
\hline Household size & $\begin{array}{l}0.048 \\
(3.22) * *\end{array}$ & $\begin{array}{l}0.046 \\
(3.12) * *\end{array}$ & $\begin{array}{l}0.046 \\
(3.13) * *\end{array}$ & $\begin{array}{l}0.045 \\
(3.04)^{* *}\end{array}$ \\
\hline Change in household size & $\begin{array}{l}\odot .036 \\
(1.46)\end{array}$ & $\begin{array}{l}\odot .039 \\
(1.59)\end{array}$ & $\begin{array}{l}\odot .033 \\
(1.34)\end{array}$ & $\begin{array}{l}\odot .036 \\
(1.47)\end{array}$ \\
\hline Number of Children $<5$ & $\begin{array}{l}-0.090 \\
(2.20) *\end{array}$ & $\begin{array}{l}-0.088 \\
(2.16)^{*}\end{array}$ & $\begin{array}{l}-0.081 \\
(2.00)^{*}\end{array}$ & $\begin{array}{l}-0.079 \\
(1.96)\end{array}$ \\
\hline $\begin{array}{l}\text { Change in the number of } \\
\text { children }<5\end{array}$ & 0.051 & 0.049 & 0.042 & 0.040 \\
\hline & $(1.49)$ & $(1.45)$ & $(1.25)$ & $(1.20)$ \\
\hline Number of Men in hh & $\begin{array}{l}-0.036 \\
(1.64)\end{array}$ & $\begin{array}{l}-0.035 \\
(1.60)\end{array}$ & $\begin{array}{l}-0.036 \\
(1.69)\end{array}$ & $\begin{array}{l}-0.036 \\
(1.65)\end{array}$ \\
\hline $\begin{array}{l}\text { Change in Number of Men in } \\
\text { hh }\end{array}$ & $\begin{array}{l}-0.030 \\
(0.91)\end{array}$ & $\begin{array}{l}-0.033 \\
(1.02)\end{array}$ & $\begin{array}{l}-0.028 \\
(0.86)\end{array}$ & $\begin{array}{l}-0.031 \\
(0.98)\end{array}$ \\
\hline Urban Dummy & $\begin{array}{l}-0.052 \\
(1.30)\end{array}$ & $\begin{array}{l}-0.049 \\
(1.20)\end{array}$ & $\begin{array}{l}-0.043 \\
(1.06)\end{array}$ & $\begin{array}{l}-0.039 \\
(0.97)\end{array}$ \\
\hline North Sumatra & $\begin{array}{l}-0.167 \\
(1.87)\end{array}$ & $\begin{array}{l}-0.237 \\
(2.58)^{* *}\end{array}$ & $\begin{array}{l}-0.157 \\
(1.76)\end{array}$ & $\begin{array}{l}-0.224 \\
(2.44)^{*}\end{array}$ \\
\hline West Sumatra & $\begin{array}{l}-0.185 \\
(1.59)\end{array}$ & $\begin{array}{l}-0.245 \\
(2.09)^{*}\end{array}$ & $\begin{array}{l}-0.195 \\
(1.68)\end{array}$ & $\begin{array}{l}-0.253 \\
(2.16)^{*}\end{array}$ \\
\hline South Sumatra & $\begin{array}{l}-0.062 \\
(0.65)\end{array}$ & $\begin{array}{l}-0.088 \\
(0.91)\end{array}$ & $\begin{array}{l}-0.042 \\
(0.42)\end{array}$ & $\begin{array}{l}-0.067 \\
(0.68)\end{array}$ \\
\hline Lampung & $\begin{array}{l}-0.189 \\
(1.83)\end{array}$ & $\begin{array}{l}-0.285 \\
(2.57)^{*}\end{array}$ & $\begin{array}{l}-0.185 \\
(1.80)\end{array}$ & $\begin{array}{l}-0.275 \\
(2.49)^{*}\end{array}$ \\
\hline West Java & $\begin{array}{l}-0.001 \\
(0.01)\end{array}$ & $\begin{array}{l}-0.043 \\
(0.63)\end{array}$ & $\begin{array}{l}0.022 \\
(0.34)\end{array}$ & $\begin{array}{l}-\odot .019 \\
(\odot .29)\end{array}$ \\
\hline Central Java & $\begin{array}{l}-0.053 \\
(0.74)\end{array}$ & $\begin{array}{l}-0.090 \\
(1.21)\end{array}$ & $\begin{array}{l}-0.045 \\
(0.62)\end{array}$ & $\begin{array}{l}-0.081 \\
(1.09)\end{array}$ \\
\hline Di Yogyakarta & $\begin{array}{l}-0.239 \\
(2.69) * *\end{array}$ & $\begin{array}{l}-0.285 \\
(3.14)^{* *}\end{array}$ & $\begin{array}{l}-0.225 \\
(2.52)^{*}\end{array}$ & $\begin{array}{l}-0.269 \\
(2.96)^{* *}\end{array}$ \\
\hline East Java & $\begin{array}{l}-0.092 \\
(1.27)\end{array}$ & $\begin{array}{l}-0.136 \\
(1.83)\end{array}$ & $\begin{array}{l}-0.078 \\
(1.08)\end{array}$ & $\begin{array}{l}-0.120 \\
(1.63)\end{array}$ \\
\hline Bali & $\begin{array}{l}-0.004 \\
(0.05)\end{array}$ & $\begin{array}{l}-0.060 \\
(0.69)\end{array}$ & $\begin{array}{r}-0.015 \\
(0.18)\end{array}$ & $\begin{array}{l}-0.069 \\
(0.79)\end{array}$ \\
\hline West NusaTenggara & -0.062 & -0.097 & -0.077 & -0.110 \\
\hline
\end{tabular}




\begin{tabular}{|c|c|c|c|c|}
\hline & $(0.68)$ & $(1.04)$ & $(0.84)$ & $(1.20)$ \\
\hline South Kalimantan & $\begin{array}{l}-0.111 \\
(1.34)\end{array}$ & $\begin{array}{l}-0.146 \\
(1.74)\end{array}$ & $\begin{array}{l}-0.120 \\
(1.43)\end{array}$ & $\begin{array}{l}-0.153 \\
(1.80)\end{array}$ \\
\hline South Sulawesi & $\begin{array}{l}0.036 \\
(0.33)\end{array}$ & $\begin{array}{l}-0.010 \\
(0.09)\end{array}$ & $\begin{array}{l}0.022 \\
(0.20)\end{array}$ & $\begin{array}{l}-0.023 \\
(0.20)\end{array}$ \\
\hline Moved Province & $\begin{array}{l}-0.243 \\
(1.84)\end{array}$ & $\begin{array}{l}\odot .929 \\
(1.29)\end{array}$ & $\begin{array}{l}-0.263 \\
(2.05)^{*}\end{array}$ & $\begin{array}{l}\odot .869 \\
(1.22)\end{array}$ \\
\hline Moved Kabupaten/Kota & $\begin{array}{l}\odot .136 \\
(1.82)\end{array}$ & $\begin{array}{l}0.100 \\
(0.24)\end{array}$ & $\begin{array}{l}0.133 \\
(1.80)\end{array}$ & $\begin{array}{l}0.062 \\
(0.15)\end{array}$ \\
\hline Moved Kecamatan & $\begin{array}{l}\odot .033 \\
(0.75)\end{array}$ & $\begin{array}{l}0.637 \\
(2.36) *\end{array}$ & $\begin{array}{l}\odot .037 \\
(0.83)\end{array}$ & $\begin{array}{l}0.620 \\
(2.31)^{*}\end{array}$ \\
\hline Moved Prov x Initial Income & & $\begin{array}{l}-0.181 \\
(1.69)\end{array}$ & & $\begin{array}{l}-0.175 \\
(1.64)\end{array}$ \\
\hline Moved Kab x Initial Income & & $\begin{array}{l}0.010 \\
(0.16)\end{array}$ & & $\begin{array}{l}0.015 \\
(0.25)\end{array}$ \\
\hline Moved Kec x Initial Income & & $\begin{array}{l}-0.097 \\
(2.31)^{*}\end{array}$ & & $\begin{array}{l}-0.094 \\
(2.25)^{*}\end{array}$ \\
\hline Non-farm dummy & $\begin{array}{l}0.362 \\
(1.99)^{*}\end{array}$ & $\begin{array}{l}0.373 \\
(2.18) *\end{array}$ & & \\
\hline Stayed Non-farm & $\begin{array}{l}-0.269 \\
(1.56)\end{array}$ & $\begin{array}{l}-0.282 \\
(1.75)\end{array}$ & $\begin{array}{l}-0.143 \\
(0.72)\end{array}$ & $\begin{array}{l}-0.155 \\
(0.80)\end{array}$ \\
\hline Moved to non-farm & $\begin{array}{l}0.082 \\
(0.92)\end{array}$ & $\begin{array}{l}0.077 \\
(0.87)\end{array}$ & $\begin{array}{l}0.082 \\
(0.93)\end{array}$ & $\begin{array}{l}0.077 \\
(0.88)\end{array}$ \\
\hline Moved to farm & $\begin{array}{l}-0.474 \\
(2.49)^{*}\end{array}$ & $\begin{array}{l}-0.499 \\
(2.76)\end{array}$ & $\begin{array}{r}-0.329 \\
(1.55)\end{array}$ & $\begin{array}{r}-0.352 \\
(1.69)\end{array}$ \\
\hline Mining_Quarry & & & $\begin{array}{r}-0.082 \\
(0.22)\end{array}$ & $\begin{array}{r}-\odot .067 \\
(0.18)\end{array}$ \\
\hline Manufacturing & & & $\begin{array}{l}0.132 \\
(0.65)\end{array}$ & $\begin{array}{l}0.143 \\
(0.72)\end{array}$ \\
\hline Electricity & & & $\begin{array}{l}0.126 \\
(0.52)\end{array}$ & $\begin{array}{l}0.144 \\
(0.59)\end{array}$ \\
\hline Construction & & & $\begin{array}{l}0.052 \\
(0.25)\end{array}$ & $\begin{array}{l}\odot .059 \\
(0.29)\end{array}$ \\
\hline Wholesale & & & $\begin{array}{l}0.292 \\
(1.42)\end{array}$ & $\begin{array}{l}0.302 \\
(1.50)\end{array}$ \\
\hline Transport & & & $\begin{array}{l}0.218 \\
(1.04)\end{array}$ & $\begin{array}{l}0.225 \\
(1.10)\end{array}$ \\
\hline Finance & & & $\begin{array}{l}0.535 \\
(2.21) *\end{array}$ & $\begin{array}{l}0.527 \\
(2.20) *\end{array}$ \\
\hline Social_services & & & $\begin{array}{l}0.450 \\
(2.16) \text { * }\end{array}$ & $\begin{array}{l}0.455 \\
(2.21) *\end{array}$ \\
\hline Constant & $\begin{array}{l}3.104 \\
(8.71) * *\end{array}$ & $\begin{array}{l}2.826 \\
(7.63) * *\end{array}$ & $\begin{array}{l}3.218 \\
(9.07) \text { ** }\end{array}$ & $\begin{array}{l}2.950 \\
(7.94) * *\end{array}$ \\
\hline Observations & 4225 & 4225 & 4225 & 4225 \\
\hline R-squared & 0.32 & 0.33 & 0.33 & 0.34 \\
\hline
\end{tabular}

Robust $t$ statistics in parentheses

$*$ significant at 5\%; ** significant at $1 \%$

Note: All variables which are not difference variables are from the IFLS 1993. 
Table 9: Geographic and Absolute Convergence

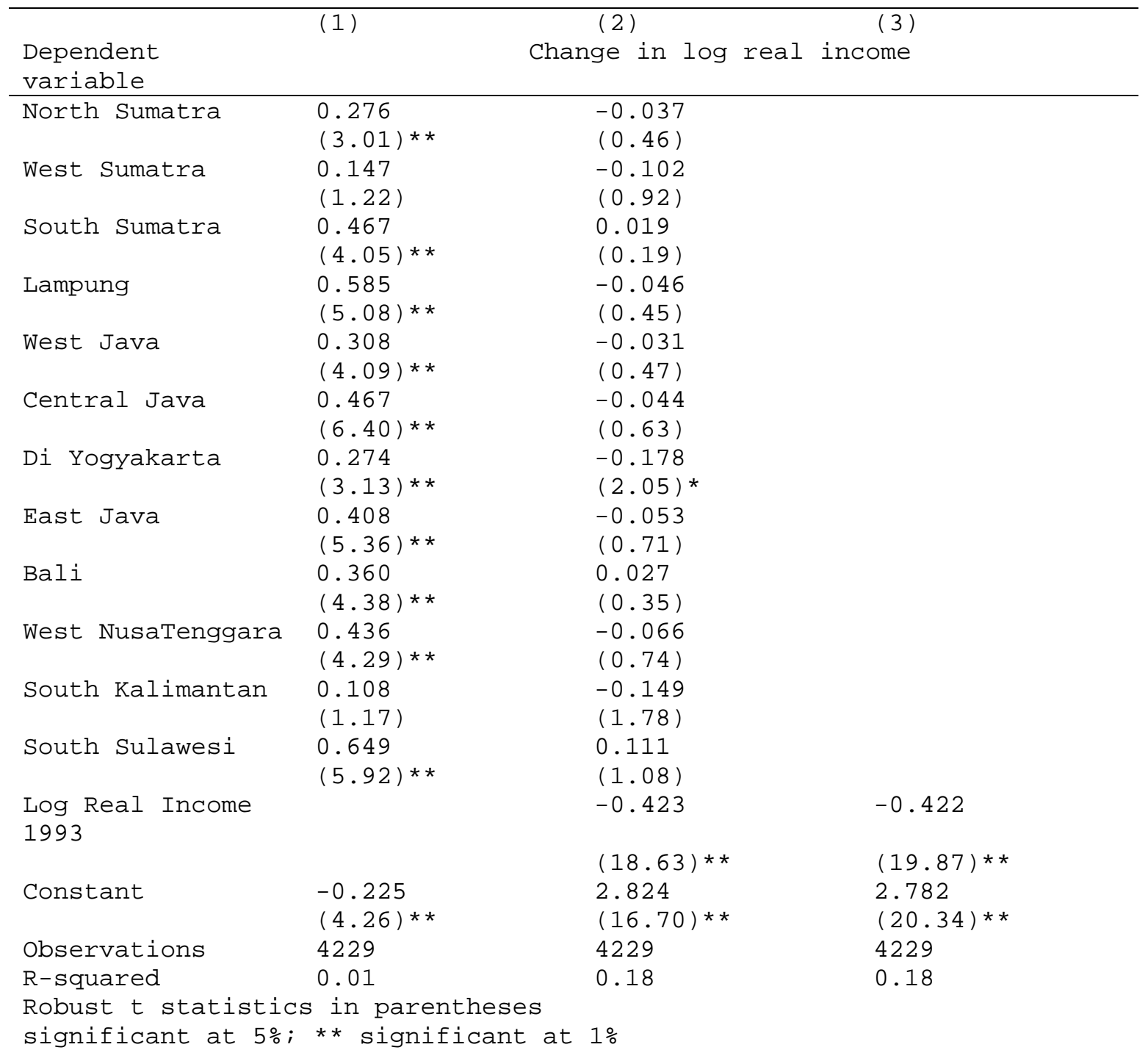


The geographical variables are not as important in explaining changes as they were in explaining levels. Individuals in regions outside Jakarta show slower income growth, but the effect is only statistically significant in a few locations. Furthermore, the coefficients on the regional dummies only display regional-specific effects after controlling for all other variables, in particular initial income. Hence, they are in some sense a measure of our ignorance, as they display the regional variation unexplained by other elements in the model specification. This can be seen clearly in Table 9, which shows income growth regressed against only initial income and the regional dummies. When growth is regressed against the regional dummies alone, it is clear that individuals living outside Jakarta generally experienced higher income growth than their counterparts in Jakarta. However, once we control for the initial level of income, all the coefficients on the regional dummies turn negative and many lose their significance as the income convergence is now captured in the initial income term.

Table 8 also explores the implications of moving location (province, district, or sub-district) on income growth through the inclusion of movement variables. The variables Moved Province, Moved Kabupaten, and Moved Kecamatan take the value one if the individual migrated to a different province, kabubaten or kecamatan over the given time period. The coefficients on these dummies are statistically insignificant in specifications (1) and (3). However, when we interact initial income with the migration dummies in specifications (2) and (4) we find that people who move relatively small distances (sub-district) tend to have stronger income growth, but only if they were initially less well off. This supports the view that local level migration can support income mobility particularly for the poor.

In order to analyze the impact of sectoral occupation on subsequent income change, a set of dummy variables was constructed to indicate whether an individual stayed in non-farm employment, moved to agriculture for those originally earning income in the non-farm sector in 1993, or moved into the non-farm sector, for those who where engaged in agriculture in 1993. The omitted variable was those individuals remaining in agriculture. Those who where engaged in non-farm activities in 1993 and stayed in the non-farm sector experienced higher than average income growth compared to individuals who remained in agriculture; their income growth was also significantly higher than that 
of individuals who moved to the farming sector, which is clearly associated with income decline. Interestingly, individuals who moved from agriculture to the non-farm sector seem to have experienced higher income growth than those remaining in agriculture, although the effect is not statistically significant. ${ }^{18}$ This helps to explain the rapid growth of the non-farm sector described above.

\section{POVERTY DYNAMICS}

The regression above tells us something about the determinants of income growth, but it tells us nothing specific about the dynamics of poverty. In order to determine what factors increase the likelihood of exiting or falling into poverty we run two Logit regressions: first we restrict the sample to people from poor households in 1993 and estimate the determinants of leaving poverty; second we restrict the sample to people from households whose per capita expenditure was above the poverty line in 1993 and look at the determinants of falling into poverty. ${ }^{19}$

Before turning to a more detailed model, Table 10 shows a simple Logit model which focuses on the transition paths described above, i.e. movement between rural and urban areas and movement in and out of agriculture. Both regressions control for initial income. Unsurprisingly, higher initial income increases the chances of exit and reduces the chances of falling into poverty. However, staying in an urban area reduces the chances of exit and increases the chances of entering poverty, another indication of the predominantly urban impact of the crisis. Neither transition to rural or urban areas is statistically significant.

On the other hand, moving into the non-farm sector, or simply staying there, are significantly associated with exiting poverty and reduce the chances of entering poverty too relative to those who stayed in agriculture. Thus the simple model gives some support to the importance of sectoral transitions in movements out of poverty.

\footnotetext{
${ }^{18}$ This takes into account the fact that the median years of schooling equals 5 years for those who moved into the non-farm sector as compared to 3 years for those remaining in agriculture

${ }^{19}$ Of course this analysis can also be done simultaneously using a multinomial logit model, but the results would be almost identical. We therefore prefer the more intuitive presentation of the two Logit models.
} 
Table 10: Simple Logit regression of poverty exit and entry (1993-2000)

\begin{tabular}{|c|c|c|}
\hline & $\begin{array}{l}\text { (1) } \\
\text { exit }\end{array}$ & $\begin{array}{l}\text { (2) } \\
\text { entry }\end{array}$ \\
\hline Log real income 1993 & $\begin{array}{l}0.119 \\
(1.61)\end{array}$ & $\begin{array}{l}-0.352 \\
(7.01) * *\end{array}$ \\
\hline Stay Urban & $\begin{array}{l}-0.768 \\
(4.11) * *\end{array}$ & $\begin{array}{l}0.317 \\
(2.28) \text { * }\end{array}$ \\
\hline Move to Rural & $\begin{array}{l}0.760 \\
(1.44)\end{array}$ & $\begin{array}{l}-0.333 \\
(0.80)\end{array}$ \\
\hline Move to Urban & $\begin{array}{l}-0.280 \\
(0.57)\end{array}$ & $\begin{array}{l}0.395 \\
(1.00)\end{array}$ \\
\hline Stay Non-farm & $\begin{array}{l}0.537 \\
(2.86) * *\end{array}$ & $\begin{array}{l}-0.385 \\
(2.46)^{*}\end{array}$ \\
\hline Move to Non-farm & $\begin{array}{l}0.601 \\
(2.46) *\end{array}$ & $\begin{array}{l}-0.336 \\
(1.47)\end{array}$ \\
\hline Move to farm & $\begin{array}{l}-0.513 \\
(1.90)\end{array}$ & $\begin{array}{l}0.079 \\
(0.37)\end{array}$ \\
\hline Constant & $\begin{array}{l}-0.536 \\
(1.34)\end{array}$ & $\begin{array}{l}0.619 \\
(2.11) *\end{array}$ \\
\hline Observations & 1186 & 3690 \\
\hline
\end{tabular}

Table 11 shows how this assessment changes when the impact of individual, household and geographical characteristics on poverty exit and entry are taken into account. Some of the determinants of income growth are not strongly associated with existing poverty. For example, neither age, nor sex, nor working hours are significantly associated with exit from poverty. The strongest effects come from education, which strongly increases the chances of exit and reduces those of entry, and from household size--large households are less likely to exit poverty and more likely to enter.

The demographic composition of the household also matters for poverty entry, with higher numbers of small children and men making falling into poverty more likely. It is not clear why having more males in the household should be associated with a higher chance of entering poverty. In most of the literature having more males is associated with higher rather than lower income, but multiple adult males in the household in this sample may reflect the impact of the crisis, as many urban construction workers returned to their village households, at least temporarily. 
Table 11: Full Logit regression of poverty exit and entry (1993-2000)

\begin{tabular}{|c|c|c|}
\hline & (1) & (2) \\
\hline & exit & entry \\
\hline Log real income 1993 & $\begin{array}{l}0.155 \\
(1.88)\end{array}$ & $\begin{array}{l}-0.295 \\
(4.75) * *\end{array}$ \\
\hline Age & $\begin{array}{l}0.098 \\
(1.38)\end{array}$ & $\begin{array}{l}-0.128 \\
(2.45) *\end{array}$ \\
\hline Age squared & $\begin{array}{l}-0.001 \\
(1.61)\end{array}$ & $\begin{array}{l}0.002 \\
(2.68) * *\end{array}$ \\
\hline Sex & $\begin{array}{l}-0.056 \\
(0.31)\end{array}$ & $\begin{array}{l}0.088 \\
(0.64)\end{array}$ \\
\hline Working hours per month & $\begin{array}{l}0.001 \\
(0.81)\end{array}$ & $\begin{array}{l}-0.001 \\
(0.79)\end{array}$ \\
\hline Wage income dummy & $\begin{array}{l}-0.153 \\
(0.95)\end{array}$ & $\begin{array}{l}0.299 \\
(2.30) *\end{array}$ \\
\hline Years of schooling & $\begin{array}{l}0.132 \\
(5.03) * *\end{array}$ & $\begin{array}{l}-0.136 \\
(7.84)^{* *}\end{array}$ \\
\hline Household size & $\begin{array}{l}-0.180 \\
(3.03)^{* *}\end{array}$ & $\begin{array}{l}0.118 \\
(2.30)^{*}\end{array}$ \\
\hline Number of Children $<5$ & $\begin{array}{l}-\odot .0 \odot 4 \\
(\odot .04)\end{array}$ & $\begin{array}{l}0.196 \\
(2.23) *\end{array}$ \\
\hline Number of Men & $\begin{array}{l}0.044 \\
(0.57)\end{array}$ & $\begin{array}{l}0.191 \\
(2.67) * *\end{array}$ \\
\hline Urban Dummy & $\begin{array}{l}-\odot .777 \\
(4.13)^{* *}\end{array}$ & $\begin{array}{l}0.535 \\
(3.53) * *\end{array}$ \\
\hline North Sumatra & $\begin{array}{l}-0.938 \\
(1.29)\end{array}$ & $\begin{array}{l}-0.128 \\
(0.34)\end{array}$ \\
\hline West Sumatra & $\begin{array}{l}0.019 \\
(0.02)\end{array}$ & $\begin{array}{l}1.315 \\
(3.68) * *\end{array}$ \\
\hline South Sumatra & $\begin{array}{l}-0.418 \\
(0.58)\end{array}$ & $\begin{array}{l}0.913 \\
(2.63) * *\end{array}$ \\
\hline Lampung & $\begin{array}{l}-0.954 \\
(1.27)\end{array}$ & $\begin{array}{l}0.471 \\
(1.18)\end{array}$ \\
\hline West Java & $\begin{array}{l}-0.322 \\
(0.50)\end{array}$ & $\begin{array}{l}0.818 \\
(2.78) * *\end{array}$ \\
\hline Central Java & $\begin{array}{l}0.128 \\
(0.20)\end{array}$ & $\begin{array}{l}0.227 \\
(0.70)\end{array}$ \\
\hline Di Yogyakarta & $\begin{array}{l}-0.166 \\
(0.24)\end{array}$ & $\begin{array}{l}\odot .686 \\
(1.94)\end{array}$ \\
\hline East Java & $\begin{array}{l}0.428 \\
(0.67)\end{array}$ & $\begin{array}{l}0.850 \\
(2.67) * *\end{array}$ \\
\hline Bali & $\begin{array}{l}0.158 \\
(0.23)\end{array}$ & $\begin{array}{l}0.672 \\
(1.94)\end{array}$ \\
\hline West NusaTenggara & $\begin{array}{l}0.277 \\
(0.41)\end{array}$ & $\begin{array}{l}1.311 \\
(3.74) * *\end{array}$ \\
\hline South Kalimantan & $\begin{array}{l}-0.071 \\
(0.10)\end{array}$ & $\begin{array}{l}0.679 \\
(1.98) \text { * }\end{array}$ \\
\hline South Sulawesi & $\begin{array}{l}0.721 \\
(1.03)\end{array}$ & $\begin{array}{l}-0.028 \\
(0.07)\end{array}$ \\
\hline Moved Province & $\begin{array}{l}3.830 \\
(3.40) * *\end{array}$ & $\begin{array}{l}0.018 \\
(0.03)\end{array}$ \\
\hline Moved Kabupaten & $\begin{array}{l}0.938 \\
(2.62) * *\end{array}$ & $\begin{array}{r}-0.203 \\
(0.94)\end{array}$ \\
\hline Moved Kecamatan & -0.105 & -0.024 \\
\hline
\end{tabular}




$\begin{array}{lll} & (\odot .58) & (\odot .16) \\ \text { Stayed Non-farm } & 0.262 & -\odot .203 \\ & (1.29) & (1.19) \\ \text { Moved to non-farm } & \odot .510 & -\odot .331 \\ & (1.87) & (1.36) \\ \text { Moved to farm } & -0.620 & -\odot .054 \\ & (2.20)^{*} & (0.24) \\ \text { Constant } & -1.908 & 1.176 \\ \text { Observations } & (1.21) & (1.07) \\ & 1185 & 3687\end{array}$

The economic characteristics of the individual also play a role. Wage earners have a higher probability of entering poverty, probably as a consequence of formerly non-poor employees falling into poverty as a result of the crisis. By contrast the initial level of working hours in 1993 has no significant influence on exit or entry.

Geography as always is important, with people living outside of Jakarta often more likely to enter poverty or less likely to exit it (although the latter effect is always statistically insignificant). Individuals from certain provinces (all of Java except central Java, South and West Sumatra, West Nusa Tenggara and South Kalimantan) appear to have been particularly vulnerable to poverty relative to those in Jakarta. The same was true of workers in urban households who, ceteris paribus, were less likely to exit poverty than their rural counterparts and more likely to enter.

Moreover, moving either province or kabubaten appears to be positively associated with exiting poverty. Such movements are not associated with entering poverty, suggesting that geographical movements are associated with things getting better rather than with distress movement as a result of a shock.

Finally, looking at the sectoral characteristics, it is interesting to note that moving to or staying in non-farm employment, which was strongly and significantly associated with poverty exit in Table 10, is no longer statistically significant. Clearly, moving to and staying in the non-farm sector is correlated with other characteristics which themselves support exit from poverty. By contrast, moving back into agriculture clearly and significantly reduces the chances of exiting poverty relative to those who stay in agriculture. 


\section{CONCLUSIONS}

This paper started with a simple question--what were the pathways out of poverty in Indonesia between 1993 and 2000? Two stylized pathways were put forward, improved productivity in agriculture and the growth of non-farm productivity; and two transitions to reach these paths were hypothesized, a sectoral transition from farm to nonfarm, and a geographical transition from rural to urban.

The results presented above suggest that there is no single or simple answer to this question. There are many factors which affect movements out of poverty. The aggregate evidence from the SUSENAS data (when "corrected" for changing administrative borders) suggests that employment growth in the rural non-farm sector has played an important role in reducing poverty. When carefully analyzed, these SUSENAS data offer useful insights into the net flows of workers across sectors and locations. But the use of cross-sectional data to understand poverty dynamics does not account for how individual, household and geographical characteristics may shape the transitions that occur.

The IFLS panel data set allows us to explore precisely these transitions between 1993 and 2000. Among the poorest individuals who were aged 15+ and working in 1993, getting out of agriculture appears to be an important factor in increasing incomes.

Almost a fifth of these individuals left agriculture and in doing so substantially increased their incomes. This said, getting out of agriculture is not the only route out of poverty. Indeed over $80 \%$ of individuals from poor households working in rural agriculture in 1993 were still working in rural agriculture seven years later, but more than half of the households from which they came managed to exit from poverty. Thus boosting agricultural productivity is also an important pathway out of poverty.

Rural-urban migration, by contrast, would appear to have a relatively small role, although this period in Indonesia's modern economic history, from 1993 to 2000, was a particularly difficult one for successful rural to urban migration. Only a handful of those working in rural agriculture in 1993 were able to migrate to urban areas. Most of those who migrated to non-farm jobs in urban areas were already doing non-agricultural jobs in rural areas and tended to be among the better off non-farm rural workers. Thus it may be that the rural non-farm sector acts as a stepping stone between rural agricultural work and more productive non-farm employment in urban areas. 
Even when the individual, household and geographical determinants of income and poverty are taken into account, our analysis yields broad support for the idea that movement to the non-farm sector increases income growth and makes exit from poverty more likely. Understandably, somewhat less support is gathered for the importance of migration, although local level migration does appear to boost income growth, particularly for the poorest, while longer range district and provincial movements are associated with an increased chance of exiting poverty.

However, it is clear that some key characteristics have a very significant influence on movements out of poverty. Age, sex and education all have a strong influence on income growth, as, negatively, do certain elements of the demographic composition of the household, most notably the household size and the number of young children. Poor schooling and large household size are also key barriers to exiting poverty, whereas a broader range of individual and demographic characteristics contribute to vulnerability.

Geography matters. The crisis hit people in urban areas harder than those in rural areas. As a result our analysis shows that being in an urban area substantially reduces the probability of exiting poverty once controlling for other factors. Similarly, once income convergence is taken into account, individuals outside Jakarta experienced slower income growth and a lower chance of exiting poverty than those in the capital.

Our analysis suffers from one important drawback. Because we are specifically interested in whether changes in the sector of employment are an important pathway out of poverty, we have had to restrict our panel to individuals who were aged 15 or over and working in 1993. This, by definition, excludes the young and the unemployed. It also excludes from our analysis new entrants into the panel in 2000. Nonetheless, although this restriction will certainly impart a bias on the calculated levels of income and poverty relative to the full sample, our sample still provides a representative picture of the impact of sectoral and geographical changes on income growth and poverty transitions.

What are the policy implications of these findings? We suggest four. First, notwithstanding the growing importance of the non-farm sector, it is still clear that the majority of the poor will remain in rural agricultural activities for some time to come. Our results suggest that boosting agricultural productivity is the principle pathway out of poverty. It would therefore seem appropriate for the government to shift resources 
towards actions which boost agricultural productivity. These might include increased spending on agricultural research, improving the extension service, reducing costs by improving rural roads, and facilitating access to and use of more modern technology.

Second, our results also highlight the key role played by the rural non-farm sector. This is an area which has been relatively neglected by policy. Improving the investment climate for the rural non-farm sector will be key to broadening access to this stepping stone out of poverty (World Bank, 2006a). Our results show that, all other things being equal, the provinces still display a growth disadvantage relative to Jakarta, suggesting the need for better market integration and infrastructure investment outside the capital. Similarly, broadening access to commercial credit for small businesses and improving access to marketing and technology will support the growth of this sector. Also, more controversially, the government may wish to reconsider the current strong policy biases against the conversion of agricultural land for non-agricultural purposes, as well as the price supports that discourage exit from agriculture. These policies may be slowing down movement along a key pathway out of poverty.

Third, our results point to a rather modest role for migration in poverty reduction, although this was not a typical period for testing this hypothesis. There can be no doubt that urbanization is proceeding rapidly, particularly on Java, with the result that many formerly rural areas are now considered to be parts of urban economic space. This process goes hand in hand with the shift towards a greater emphasis on non-farm activities. Again the role of policy here should be to support and facilitate this change by ensuring that newly urbanized areas have access to the economic and social services needed to reduce urban poverty.

Finally, our analysis reiterates the importance of education for exiting poverty. While sectoral change and migration have a role to play, improved education is still one of the most effective routes out of poverty, for two reasons. First, better education enables people to participate in higher productivity activities. Second, better education raises the probability of being able to make the sectoral and locational changes that give access to the other pathways out of poverty. Ensuring that the poor have access to education, including post-primary education, should therefore be a cornerstone of the government's anti-poverty strategy. 


\section{References}

Besley, Timothy, Robin Burgess and Berta Esteve-Volart. 2006. "The Policy Origins of Poverty and Growth in India." In Besley and Cord, eds., Delivering on the Promise of Pro-Poor Growth. Palgrave Macmillan and the World Bank, New York, pp. 59-78.

Besley, Timothy, and Louise Cord, eds. 2006. Delivering on the Promise of Pro-Poor Growth. Palgrave Macmillan and the World Bank, New York.

Bidani, Benu and Martin Ravallion 1993. “A Regional Poverty Profile for Indonesia.” Bulletin of Indonesian Economic Studies, Volume 29, Number 3 / December 1993, pp. 37 - 68

Byerlee, Derek. 1973. "Indirect Employment and Income Distribution Effects of Agricultural Development Strategies: A Simulation Approach Applied to Nigeria." African Rural Employment Paper, No. 9, Michigan State University, East Lansing, MI.

Datt, Guarav and Martin Ravallion. 1998. "Farm Productivity and Rural Poverty in India," Journal of Development Studies, Vol. 34, pp. 62-85.

Delgado, L. Chris, J. Hopkins, and V. A. Kelly. 1998. Agricultural Growth Linkages in Sub-Saharan Africa. IFPRI Research Report 107. Washington, DC: IFPRI.

Deininger, K., Jin, S. and M. Sur, "Sri Lanka's rural non-farm economy: Removing constraints to pro-poor growth," forthcoming

Dollar, David, and Aart Kraay. 2002. "Growth is Good for the Poor." Journal of Economic Growth. Vol. 7, pp.195-225.

Fan, Shenggen, Peter Hazell and S. K. Thorat. 2000. "Government Spending, Agricultural Growth and Poverty in Rural India," American Journal of Agricultural Economics, Vol. 82, No. 4, pp. 10381051.

Fan, Shenggen, L. Zhang and X. Zhang. 2002. Growth, Inequality and Poverty in Rural China: The Role of Public Investments. IFPRI Research Report 125, International Food Research Institute, Washington, DC.

Fan, Shenggen., S. K. Thorat, and Neetha Rao. 2004. Investment, Subsidies, and Pro-Poor Growth in Rural India, in Andrew Dorward, et al., eds. (2004), Institutions and Policies for Pro-Poor Agricultural Growth: Report on Project 7989, Department for International Development Social Science Research Unit.

Fields, G et al. 2003. "For richer or for poorer? Evidence from Indonesia, South Africa. Spain, and Venezuela." Journal of Economic Inequality 1: pp. 67-99

Foster, Andrew D., and Mark R. Rosenzweig. 2004. "Agricultural Productivity Growth, Rural Economic Diversity, and Economic Reforms: India, 1970-2000." Economic Development and Cultural Change 52.3 (April): pp. 509-542.

Grimm, M and Günther, I, 2006, "Measuring Pro-Poor Growth when Relative Prices shift". Journal of Development Economics, forthcoming

Haggblade, Steven, Peter Hazell and James Brown, 1989, "Farm-Nonfarm Linkages in Rural Sub-Saharan Africa“, World Development, Vol. 17 No 8: 1173-1201 
Haggblade, Steven, Jeffrey Hammer, and Peter Hazell. 1991. "Modelling Agricultural Growth Multipliers,” American Journal of Agricultural Economics, Vol. 73, No. 2, pp. 361-74.

Haggblade, Steven, Peter Hazell and Thomas Reardon, 2002 "Strategies for Stimulating Poverty-alleviating Growth in the Rural Non-farm Economy in Developing Countries." Environment and Production Technology Division Discussion Paper 92. IFPRI, Washington, D.C.

Hayami, Y., and V. Ruttan. 1985. Agricultural Development: An International Perspective. Revised and expanded edition. Baltimore: Johns Hopkins University Press.

Hazell, Peter, and Steven Haggblade. 1993. "Farm-Nonfarm Growth Linkages and the Welfare of the Poor." In Michael Lipton and Jacques van der Gaag, eds., Including the Poor: Proceedings of a Symposium Organized by the World Bank and the International Food Policy Research Institute. The World Bank: Washington, DC.

Hazell, Peter, and Ailsa Roell. 1983. Rural Growth Linkages: Household Expenditure Patterns in Malaysia and Nigeria. IFPRI Research Report 41, Washington, DC.

Johnston, B.F., and J.W. Mellor. 1961. "The Role of Agriculture in Economic Development.” American Economic Review. Vol. 51, no. 4, pp. 566-93.

King, Robert. P. and Derek Byerlee. 1978. "Factor Intensity and Locational Impacts of Rural Consumption Patterns in Sierra Leone." American Journal of Agricultural Economics. Vol. 60, No. 2, pp. 197-206.

Klump, Ranier. 2006. “Pro-Poor Growth in Vietnam: Miracle or Model?” In Besley and Cord, eds., Delivering on the Promise of Pro-Poor Growth. Palgrave Macmillan and the World Bank, New York, pp. 119-146.

Lanjouw, Jean and Peter Lanjouw. 2001. "The Rural Non-Farm Sector: Issues and Evidence from Developing Countries. Agricultural Economics. Vol. 26, No. 1, pp. 1-23.

Larson, Donald and Yair Mundlak, 1997, "On the Intersectoral Migration of Agricultural Labor" Economic Development and Cultural Change, Vol. 45, No. 2 (Jan., 1997), pp. 295-319

Lewis, W. Arthur. 1954. "Economic Development with Unlimited Supplies of Labor." The Manchester School. Vol. 22, pp. 3-42.

Majid, Nooman. 2004. "Reaching Millennium Goals: How Well Does Agricultural Productivity Growth Reduce Poverty?” Employment Strategy Paper 2004/12, International Labor Organization (ILO), Geneva.

McCulloch, Neil and Cao Yiying. 2006. "What Caused Changes In Household Income and Poverty in Rural Sichuan in the early 1990s?”, Institute of Development Studies, University of Sussex, mimeo.

Mellor, John W. 1976. The New Economics of Growth: A Strategy for India and the Developing World. Ithaca, NY: Cornell University Press.

. 2000. "Agricultural Growth, Rural Employment, and Poverty Reduction: Non-Tradables, Public Expenditure, and Balanced Growth.” Prepared for the World Bank Rural Week 2000, March.

Mellor, John W., and Uma Lele. 1973. "Growth Linkages of the New Food Grain Technologies." Indian Journal of Agricultural Economics. Vol. 18, No. 1, pp. 35-55. 
Ravallion, Martin. 2004. "Pro-Poor Growth: A Primer." The World Bank, Policy Research Working Paper No. 3242.

Ravallion, Martin, and Shaohua. Chen. 2004. “China’s (Uneven) Progress Against Poverty.” Development Research Group, World Bank, Washington, DC., August, Processed

Ravallion, Martin., and G. Datt. 1996. "How Important to India's Poor Is the Sectoral Composition of Economic Growth?" The World Bank Economic Review. Vol. 10, no. 1, pp. 1-25.

. 1998. "Why Have Some Indian States Done Better than Others at Reducing Rural Poverty?" Economica, Volume 65 Issue 257, February, pp. 17- .

. 2002a. "Why Has Economic Growth Been More Pro-Poor in Some States of India than Others?", Journal of Development Economics, Volume 68 pp 381-400.

Ravallion, Martin, and Monika Huppi. 1991. "Measuring Changes in Poverty: A Methodological Case Study of Indonesia during an Adjustment Period." World Bank Economic Review. Vol. 5, no. 1, pp. 57-82.

Sen, Binayak, Mustafa K. Mujeri and Quazi Shahabuddin. 2006. "Explaining Pro-Poor Growth in Bangladesh." In Besley and Cord, eds., Delivering on the Promise of Pro-Poor Growth. Palgrave Macmillan and the World Bank, New York, pp. 79-118.

Smith, L. E. D., and I. Urey. 2002. "Agricultural Growth and Poverty Reduction: A Review of Lessons from the Post-Independence and Green Revolution Experience in India." Research project on Institutions and Economic Policies for Pro-Poor Agricultural Growth, funded by the Department for International Development (DfID) of the United Kingdom. Department of Agricultural Sciences, Imperial College at Wye, (October), processed.

Sumarto, Sudarno, and Asep Suryhadi. 2003. "The Indonesian Experience on Trade Reform, Economic Growth and Poverty Reduction," Presented at the Trade, Growth and Poverty Conference, December 8-9, London. The SMERU Research Institute, Jakarta, processed.

Thirtle, Colin, Lin Lin, and Jenifer Piesse. 2003. "The Impact of Research-Led Agricultural Productivity Growth on Poverty Reduction in Africa, Asia and Latin America," World Development, Vo. 31, No. 12, pp. 1959-1975.

Tiffin, Richard, and Irz, Xavier. 2006. "Is Agriculture the Engine of Growth?" Agricultural Economics, Vol. 35, pp. 79-89.

Timmer, C. P. 1988. "The Agricultural Transformation," in H. Chenery and T.N. Srinivasan, eds., Handbook of Development Economics. Vol. 1. Amsterdam: North-Holland, pp. 275-331.

. 1995. "Getting Agriculture Moving: Do Markets Provide the Right Signals?" Food Policy, Vol. 20, no. 5, pp. 455-72.

. 1997. "How Well do the Poor Connect to the Growth Process?" Harvard Institute for International Development for the USAID/CAER project, December, processed.

. 2002. "Agriculture and Economic Growth," in Bruce Gardner and Gordon Rausser, eds., Handbook of Agricultural Economics, Vol. IIA. Amsterdam: North-Holland. . 1487-1546.

. 2004. "The Road to Pro-Poor Growth: Indonesia's Experience in Regional Perspective." Bulletin of Indonesian Economic Studies, Vol. 40, no. 2 (August), pp. 177-207. 
. 2006. "How Indonesia Connected the Poor to Rapid Economic Growth." In Besley and Cord, eds., Delivering on the Promise of Pro-Poor Growth. Palgrave Macmillan and the World Bank, New York, pp. 29-58.

World Bank. 2004a. "Operationalizing Pro-Poor Growth.” A Research Project Sponsored by AFD, DFID, GTZ, KfW and PREM. Washington, DC.

. 2004b. "Promoting the Rural Non-Farm Sector in Bangladesh." Rural Development Unit, South Asia Region, Team led by Forhad Shilpi, (August), processed in two volumes.

. 2004c. Directions in Development: Agriculture and Poverty Reduction. Agriculture and Rural Development Department. September.

. 2006a. Revitalising the Rural Economy: An assessment of the investment climate faced by non-farm enterprises at the District level. Jakarta, Indonesia, July.

. 2006b. Making the New Indonesia Work for the Poor. Jakarta, Indonesia, December.

. 2006c. The Rural Investment Climate: It Differs and it Matters. Washington, DC. 